\title{
9. STRUCTURE AND PETROLOGY OF HYDROTHERMAL VEINS IN GABBROIC ROCKS FROM SITES 921 TO 924, MARK AREA (LEG 153): ALTERATION HISTORY OF SLOW-SPREAD LOWER OCEANIC CRUST ${ }^{1}$
}

\author{
Yildirim Dilek, ${ }^{2}$ Pamela D. Kempton, ${ }^{3}$ Peter Thy, ${ }^{4}$ Stephen D. Hurst, ${ }^{5}$ Donna Whitney, ${ }^{6}$ and Deborah S. Kelley ${ }^{7}$
}

\begin{abstract}
Gabbros recovered during Ocean Drilling Program (ODP) Leg 153 from Sites 921 to 924 in the Mid-Atlantic Ridge at the Kane Transform (MARK) area display metamorphic and structural features that record a complex alteration and deformational history of lower crustal rocks formed in a slow-spreading ridge environment. Exposures of gabbroic rocks on the western wall of the Mid-Atlantic Ridge, nearly $10 \mathrm{~km}$ west of the spreading axis and about $6 \mathrm{~km}$ south of the Kane Fracture Zone, indicate their rapid unroofing within 500,000 to $750,000 \mathrm{yr}$ via faulting and block uplifting near the ridge-transform intersection. Hydrothermal vein assemblages in the gabbroic rocks reflect an alteration chronology that has accompanied crystal-plastic and brittle deformational episodes, as the lower crust was emplaced on the median valley wall. Hydrothermal alteration began preferentially within and along locally developed extensional discrete shear zones, which acted as high-permeability pathways for $\mathrm{Na}$-rich fluids that caused albite enrichment in the plagioclase and Fe enrichment in the clinopyroxene. The concentration of Fe-Ti oxides along some of these discrete shear zones suggests that the shear zones also controlled late magmatic (evolved) and subsolidus fluid flow in the gabbroic rocks. Crack networks within and adjacent to the discrete shear zones facilitated amphibole veining with progressive cooling of the rocks below $500^{\circ} \mathrm{C}$. Amphibole compositions in veins changed from pargasitic and edenitic hornblende to actinolitic hornblende and actinolite, in parallel with the disappearance of secondary clinopyroxene, accompanying the gradual lowering of temperatures from amphibolite facies to greenschist/amphibolite transitional facies metamorphic conditions. Changes in the compositions of vein amphibole and vein chlorite resulted from combined effects of progressive cooling and changing water/rock ratios and water/rock reactions. Development of amphibole-chlorite and chlorite veins was facilitated by penetration of hydrothermal fluids into the lower oceanic crust along distributed microfractures, cataclastic zones, and shear zones with further cooling that attended continued tectonic extension and crustal stretching. This stage of veining overprinted the previously developed deformation fabrics and hydrothermal veins and resulted in retrograde metamorphism under greenschist metamorphic conditions in and around the discrete shear zones. Chlorite compositions indicate temperatures of chlorite equilibration of $150^{\circ}-200^{\circ} \mathrm{C}$ based on an empirical chlorite solid-solution geothermometer. Rare subvertical composite veins that are composed of epidote \pm plagioclase \pm quartz \pm prehnite \pm oxide \pm and clay minerals are probably related to cracking front in the exhumed lower oceanic crust, and may represent sealed cracks developed during emplacement of the gabbroic rocks on the seafloor. Cataclastic zones in the uppermost sections of some of the holes and in certain intervals at depth show renewed hydrothermal alteration via moderate fluid/rock ratios and represent extensional faults associated with the emplacement of the gabbroic rocks in the ridge-transform intersection massif. The vein chronology and deformation fabrics in gabbroic rocks from Sites 921 to 924 are similar to those documented from ODP Hole 735B on the Southwest Indian Ridge, and indicate that the circulation of hydrothermal fluids in gabbroic rocks at MARK occurred at progressively lower temperatures through time as the slow-spread oceanic lower crust was emplaced on the seafloor. These characteristic features of the hydrothermal alteration and spatial and temporal relations between deformation fabrics and hydrothermal alteration in slow-spread oceanic crust differ from those observed in fast-spreading oceanic crust and in the Semail ophiolite, in which hydration occurred uniformly along microfractures and crack networks that developed as a result of downward propagation of cracking front.
\end{abstract}

\section{INTRODUCTION}

Ocean Drilling Program (ODP) Sites 921-924 are located on the western wall of the Mid-Atlantic Ridge in the MARK area (MidAtlantic Ridge at Kane Transform) nearly $6 \mathrm{~km}$ south of the eastern intersection of the Kane Transform (Fig. 1A). Previous Alvin and

'Karson, J.A., Cannat, M., Miller, D.J., and Elthon, D. (Eds.), 1997. Proc. ODP, Sci. Results, 153: College Station, TX (Ocean Drilling Program).

${ }^{2}$ Department of Geology and Geography, Vassar College, Poughkeepsie, NY 12601, U.S.A. Present address: Department of Geology, Miami University, Oxford, OH 45056, U.S.A. dileky@muohio.edu

${ }^{3}$ NERC Isotope Geosciences Laboratory, Kingsley Durham Centre, Keyworth. NG12 5GG United Kingdom.

${ }^{4}$ Department of Geology, University of California, Davis, CA 95616, U.S.A.

'Department of Geology, Duke University, Durham, NC 27708, U.S.A. U.S.A.

${ }^{6}$ Department of Geology, University of North Carolina, Chapel Hill, NC 27599.

'School of Oceanography, University of Washington, Seattle, WA 98195, U.S.A. dredge programs in this area show that the ridge-transform massif exposed at the intersection is composed of extensive outcrops of gabbro, metagabbro, metabasalt, metadiabase, and lesser amount of serpentinized peridotite (Dick et al., 1981; Karson and Dick, 1983; Mével et al., 1991; Auzende et al., 1993; Cannat, Karson, Miller, et al., 1995). These rocks are exposed in a complex juxtaposition along east-facing escarpments that correspond to high-angle faults, which commonly crosscut some east-northeast dipping gentle faults along the east face of the ridge-transform intersection massif (Karson and Dick, 1983; Mével et al., 1991; Cannat, Karson, Miller, et al., 1995).

Gabbroic samples previously collected from the massif, via dredges as well as Alvin and Nautile dives, include variably deformed and metamorphosed olivine gabbro, through gabbronorite and ferrogabbro to trondhjemite (Karson and Dick, 1983; Mével et al., 1991; Marion et al., 1991; Gillis et al., 1993). These plutonic rocks record a complex history of alteration and deformation starting at temperatures in excess of $700^{\circ} \mathrm{C}$ and continuing down to $330^{\circ}-180^{\circ} \mathrm{C}$ (Kelley and Delaney, 1987; Gillis et al., 1993; Kelley et al., 1993). Mineral 


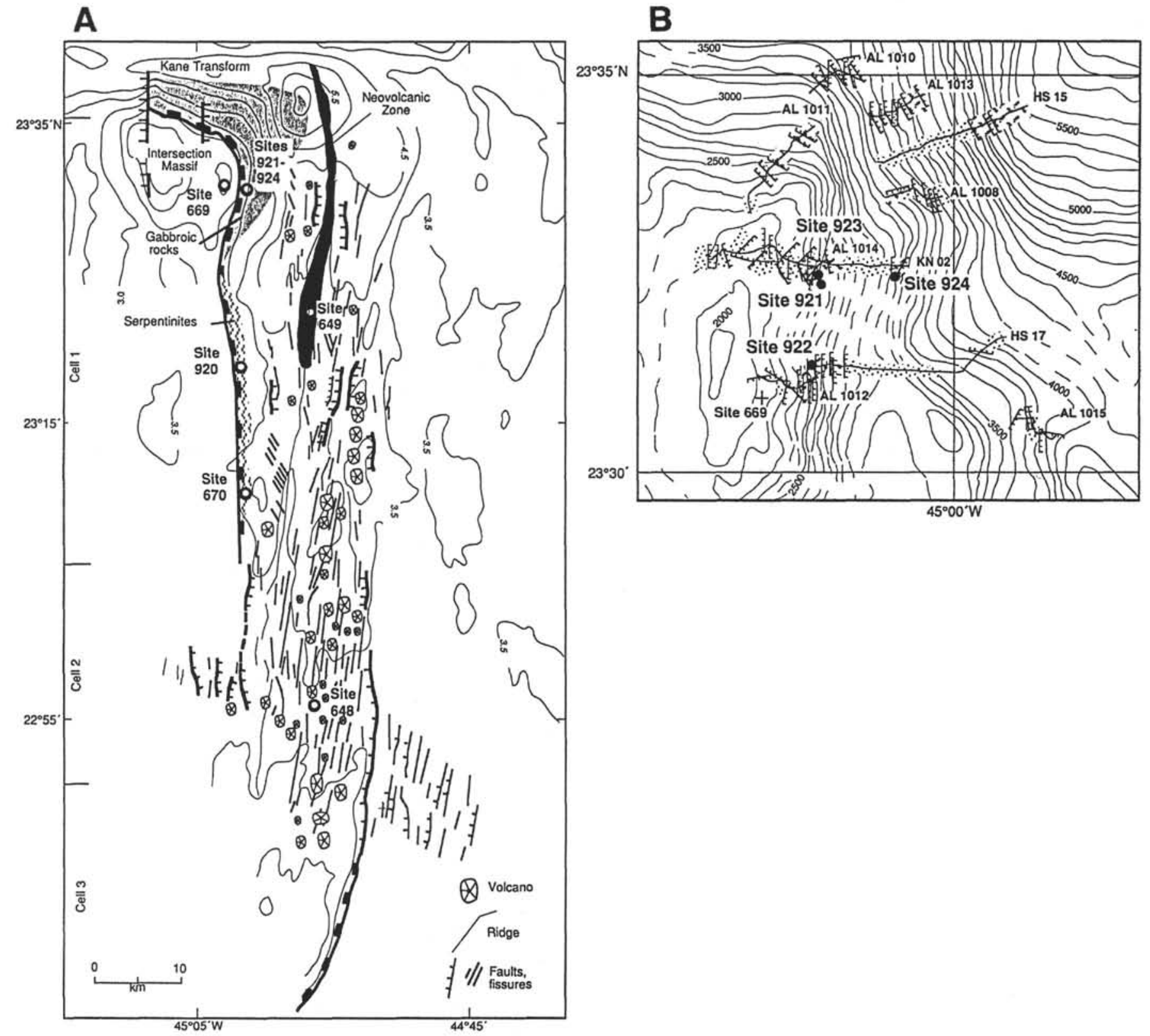

Figure 1. A. General bathymetric map of the MARK area. ODP sites are shown as open circles. Gabbroic outcrops are located in the ridge-transform intersection massif south of the Kane Transform. B. Bathymetric map of the western wall of the Mid-Atlantic Ridge in the MARK area. Sites $921-924$ and dive tracks of Alvin and Nautile are shown.

assemblages in ductile shear zones in some of the metamorphosed gabbroic rocks record high-temperature deformation and recrystallization. These zones may have facilitated the penetration of fluids into the lower crust, resulting in localized pervasive high-temperature alteration at temperatures above $500^{\circ} \mathrm{C}$ (Mével et al., 1991; Gillis et al., 1993; Kelley et al., 1993). Fractures and microfractures in the gabbroic rocks that are filled with lower amphibolite to greenschist facies mineral assemblages indicate that the plutonic sequence has undergone brittle deformation during progressive cooling throughout the subsolidus regime, following the high-temperature plastic deformation. The corresponding increase in alteration intensity with the distribution of veins indicates that the degree of alteration in the gabbroic rocks was to a large extent controlled by these brittle structures (Gillis et al., 1993).

In 1994, ODP successfully drilled Sites 920-924 (Leg 153) at the MARK area (Fig. 1B) to investigate the relationships among mag- matic, tectonic, and hydrothermal processes operating during accretion of upper mantle and lower crustal rocks and their exhumation on the seafloor in a slow-spreading ridge environment $(\sim 25 \mathrm{~mm} / \mathrm{yr})$. Hydrothermal vein assemblages in these rocks are an integral part of the tectonic history of the slow-spread oceanic lithosphere in the MARK area, and they provide significant information on its tectonic and hydrothermal evolution. This study documents the occurrence, phase chemistry, and development of hydrothermal vein assemblages and discrete shear zones in gabbroic rocks from Sites 921 to 924 to constrain the nature and the mode of hydrothermal alteration during progressive cooling of lower crustal rocks as they were emplaced on the seafloor via tectonic extension. Findings of this study are compared to the information and data available from other studies in this area and from Site 735 along the Southwest Indian Ridge, East Pacific Rise, and the Semail ophiolite to derive some conclusions on the nature of hydrothermal alteration in oceanic lithosphere with varying 
spreading rates and magma supplies. The fluid evolution in these rocks are discussed in a companion chapter (Kelley, this volume).

\section{GEOLOGY OF SITES 921-924}

Sites 921-923 are located on a series of gabbroic outcrops at about $2500 \mathrm{~m}$ water depth on the western median valley of the MidAtlantic Ridge; Site 924 is situated at nearly 3400 meters below sea level (mbsl) and $1.7 \mathrm{~km}$ east of the other three sites (Fig. 1B). Gabbroic rocks from Sites 921 to 924 are structurally heterogeneous and record a wide variation in structural styles and intensities on different scales (Cannat, Karson, Miller, et al., 1995).

At Site 921 , a total of $43 \mathrm{~m}$ of gabbroic rocks was recovered from the $246 \mathrm{~m}$ cored at the five holes drilled (Holes 921A-921E), with a cumulative recovery of $17.6 \%$ (Cannat, Karson, Miller, et al., 1995). The recovered rocks include gabbro and olivine gabbro, with lesser troctolite, gabbronorite, and iron-titanium oxide gabbro that display large variations in composition, grain size, texture, degree of deformation, and extent of alteration (Casey, this volume). Millimetric to decimetric veins of altered leucogabbro, quartz diorite, and trondhjemite crosscut these rocks, and represent end products of more extensive melt fractionation (Cannat, Karson, Miller, et al., 1995). Nearly $50 \%$ of the gabbroic rocks from Site 921 display coarse- to medium-grained primary cumulate to poikilitic textures with random orientation of primary igneous minerals. Locally, welldeveloped preferential orientation of clinopyroxene grains and elongation of subhedral plagioclase laths have produced a magmatic fabric in these rocks that is interpreted to have resulted from crystal accumulation and/or magmatic flow (Cannat, Karson, Miller, et al., 1995). This magmatic fabric is locally overprinted by crystal-plastic deformation fabrics that are defined by a shape-preferred orientation of elongated olivine and pyroxene porphyroclasts with asymmetric recrystallized tails and/or by discrete shear zones. The upper sections of Holes 921B and 921C include dm-thick cataclastic domains, which are characterized by closely spaced shear zones and elongated clasts of the primary minerals in a very fine-grained cataclastic matrix.

Site 922 is located nearly $2 \mathrm{~km}$ south of Site 921 (Fig. 1B) on a terrace sloping $15^{\circ}$ to $25^{\circ}$ to the east and in an area that is characterized by extensive outcrops of massive to foliated gabbroic rocks. A total of $21.6 \mathrm{~m}$ of gabbroic rocks was recovered from the $52 \mathrm{~m}$ cored at the two holes (Holes 922A and 922B). The majority of the rocks at this site are composed of troctolite and olivine gabbro, with local occurrences of irregular bands of oxide-bearing gabbros and leucocratic veins (Cannat, Karson, Miller, et al., 1995). Cumulate to poikilitic textures and the magmatic foliation in these rocks are overprinted by locally well-developed discrete shear zones. Some of these shear zones coincide with lithological boundaries between gabbros and troctolitic gabbros.

Site 923 lies nearly $200 \mathrm{~m}$ north of Site 921 and about $6 \mathrm{~km}$ south of the Kane fracture zone (Fig. 1B). A total of $40.76 \mathrm{~m}$ of gabbroic rocks was recovered during drilling to a depth of $70.0 \mathrm{~m}$ in Hole $923 \mathrm{~A}$. The dominant rock types recovered at this site include olivine gabbro, gabbro, troctolite, and poikilitic olivine gabbro that are commonly texturally heterogeneous (Cannat, Karson, Miller, et al., 1995). Preferred dimensional orientation of elongate plagioclase and/ or clinopyroxene crystals locally defines a weak magmatic foliation in these rocks, and porphyroclastic to gneissic textures are generally concentrated in cm-scale discrete shear zones.

Site 924 is located $1.7 \mathrm{~km}$ east and downslope from Sites 921 and 923 (Fig. 1B). Holes 924B and $924 \mathrm{C}$ recovered a total of $11.49 \mathrm{~m}$ of gabbroic rocks (no recovery from Hole 924A), consisting predominantly of weakly deformed and variably altered olivine gabbro and troctolite (Cannat, Karson, Miller, et al., 1995). These rocks display locally developed weak foliations and lineations characterized by shape-preferred orientation of olivine, clinopyroxene, and plagio- clase (e.g., Sample 153-924C-6R-1, 30-67 cm). These crystal-plastic deformation fabrics occur in $\mathrm{cm}$ - to dm-thick bands that show gradational boundaries with the adjacent undeformed rock. Discrete shear zones observed at Sites 921 to 923 are rare to absent at Site 924 .

\section{STRAIN LOCALIZATION AND METAMORPHISM IN DISCRETE SHEAR ZONES}

Localized ductile to semibrittle shear zones form discrete zones of high strain relative to the surrounding rock and have deformation fabrics that range from moderately recrystallized to mylonitic. The distribution of these discrete shear zones throughout the cores from Sites 921 to 924 is heterogeneous and does not show any systematic pattern. Their width varies from $\mathrm{mm}$ - to dm-scales; their orientation is also highly variable in the cores, ranging from subhorizontal to subvertical, and anastomosing branches and splays with different dip angles and directions are common (i.e., Sample 153-921B-3R-1, 33-63 $\mathrm{cm}$ ).

Shear zones commonly have sharp and well-defined boundaries, and gabbroic rocks adjacent to them are generally undeformed with no shape-preferred orientation. However, in some cases there is a progressive increase in preferred coalignment of plagioclase and clinopyroxene grains of the host rock toward the shear zone (e.g., Sample 153-921E-2R-2, Piece 7). Locally, several closely spaced discrete shear zones in certain intervals in the core form a gneissic texture characterized by asymmetric plagioclase and clinopyroxene porphyroclasts and bands of iron oxide minerals (e.g., Samples 153-922A2R-2, 106-125 cm; 922B-1W-1, 105-112 cm; 923A-2R-1, Piece 11). In places, a strongly developed mineral lineation of olivine and plagioclase grains in the host rock accompanies this gneissic texture between the shear zones (e.g., Sample 153-922B-1W-2, Pieces 1 and 2).

Discrete shear zones are locally spatially associated with sulfide and/or oxide mineral concentrations, which display well-developed foliation and lineation parallel to the crystal-plastic fabric within the shear zones (Cannat, Karson, Miller, et al., 1995). In Sample 153922B-1W-1, 105-111 cm, for example, deformed Fe-Ti oxide minerals occur as elongated stringers parallel to the shear zone fabric, and they are in turn crosscut by amphibole and actinolite-chlorite veins. Shear zones and associated oxide minerals are locally situated along lithological boundaries separating gabbroic rocks with different igneous and metamorphic textures (Cannat, Karson, Miller, et al., 1995). In Sample 153-922B-2R-1 (Piece 2A), a 5- to 15-mm-wide and steeply dipping shear zone separates anorthositic deformed olivine gabbro above from undeformed olivine gabbro below and contains stringers of oxide and sulfide minerals.

The internal texture of discrete shear zones is characterized by well-developed, shape-preferred orientations of recrystallized olivine and clinopyroxene alternating with plagioclase-rich bands. Extreme grain-size reduction and a bimodal grain-size distribution of clinopyroxene and plagioclase characterize a porphyroclastic texture (e.g., Sample 153-923A-3R-2, Piece 2), whereas alternating bands of finer grained plagioclase- and pyroxene/olivine-rich horizons define gneissic textures (e.g., Sample 153-923A-2R-2, Piece 1) within the shear zones. While plagioclase and olivine neoblasts display moderately to well-developed mosaic textures, clinopyroxene neoblasts form elongated tails around clinopyroxene porphyroclasts, producing strongly developed, multimodal grain-size distributions in and across the shear zones. Locally, subhedral plagioclase porphyroclasts display a moderately developed preferred orientation of mechanical twins (e.g., Sample 153-922A-2R-2, 106-111 cm). The porphyroclastic texture in some shear zones is accentuated by discontinuous, narrow stringers of pale green to dark green, fibrous hornblende (e.g., Sample 153-923A-2R-2, 15-47 cm).

Kinematic indicators within and along discrete shear zones suggest mainly a normal sense of shearing. In Sample 153-922B-3R-2 
(Piece 3A), a 7-mm-wide discrete shear zone contains plagioclase and clinopyroxene porphyroclasts with asymmetric tails, which show a normal sense of shearing. The boundary between a coarse-grained olivine gabbro and a very coarse-grained gabbro is offset for $2.5 \mathrm{~cm}$ along this normal shear zone, indicating that some of these shear zones are associated with faulting. In Sample 153-923A-11R-1 (Piece 8), there are two, mm-scale, ultramylonitic shear zones that are discordant to the foliation in the gneissic gabbro. The compositional banding and elongated porphyroclastic texture in the gneissic gabbro display drag features along the shear zone boundaries that indicate a normal sense of shearing. In Piece 9 in the same sample, a 1 -cm-thick mylonitic shear zone separates a foliated gabbro above from an undeformed gabbro below and has a dip of $50^{\circ}$. Drag of the foliation in the deformed gabbro and asymmetric tails of clinopyroxene porphyroclasts in the shear zone show a normal sense of shearing. In Sample 153-923A-16R-2, 32-44 cm, two subparallel, cm-scale shear zones display sharp boundaries with the olivine gabbro host rock and have a well-developed porphyroclastic texture with strongly crystallized plagioclase and clinopyroxene porphyroclasts. Dynamically recrystallized asymmetric tails of the clinopyroxene show a normal sense of shearing along these shear zones. These observations suggest that brittle-plastic deformation that produced the discrete shear zones in the gabbroic rocks at Sites 921-924 was associated with extension and stretching of the lower oceanic crust.

Changes in the mineral chemistry of plagioclase and clinopyroxene across a representative shear zone and a microgabbro vein in the gabbroic rocks from Holes 922A and 923A, respectively, were examined through 350 to 500 point analyses using an electron microprobe (CAMECA Camebax at the University of California, Davis) along single profiles across the shear zone and the microgabbro vein. The 10-mm-thick shear zone in Sample 153-922A-2R-2, 2-5 cm, dips moderately $\left(36^{\circ}\right)$ and has sharp boundaries with the olivine gabbro host rock (Fig. 2). The shear zone includes lenses and bands of recrystallized plagioclase and brown hornblende and strongly recrystallized olivine and clinopyroxene porphyroclasts. The plagioclase shows a bimodal grain-size distribution, with small neoblasts forming a mantle around large single grains (cores) that display patchy extinction. Mechanical twins in most plagioclase cores are aligned parallel to the foliation/banding within the shear zone. Clinopyroxene porphyroclasts are kinked and have neoblasts along their edges. Asymmetric olivine porphyroclasts contain small neoblasts with subgrains and irregular sutured boundaries and show dextral or down-dip (normal) sense of shearing (Fig. 2). The plagioclase chemistry across the shear zone shows significant fluctuations in Na content and albite enrichment in channels through plagioclase neoblasts (Figs. 3, 4). In parallel with this change in plagioclase chemistry, the $\mathrm{Mg}$ number of the clinopyroxene (augite) is reduced across the shear zone, suggesting Fe enrichment in the recrystallized augite.

The 8-mm-thick microgabbro vein in Sample 153-923A-12R-2, $22-39 \mathrm{~cm}$, dips steeply $\left(60^{\circ}-65^{\circ}\right)$ and displays generally sharp boundaries with the gabbro and olivine gabbro host rock (Fig. 5). Extreme grain-size reduction across the vein-host rock boundaries is

A

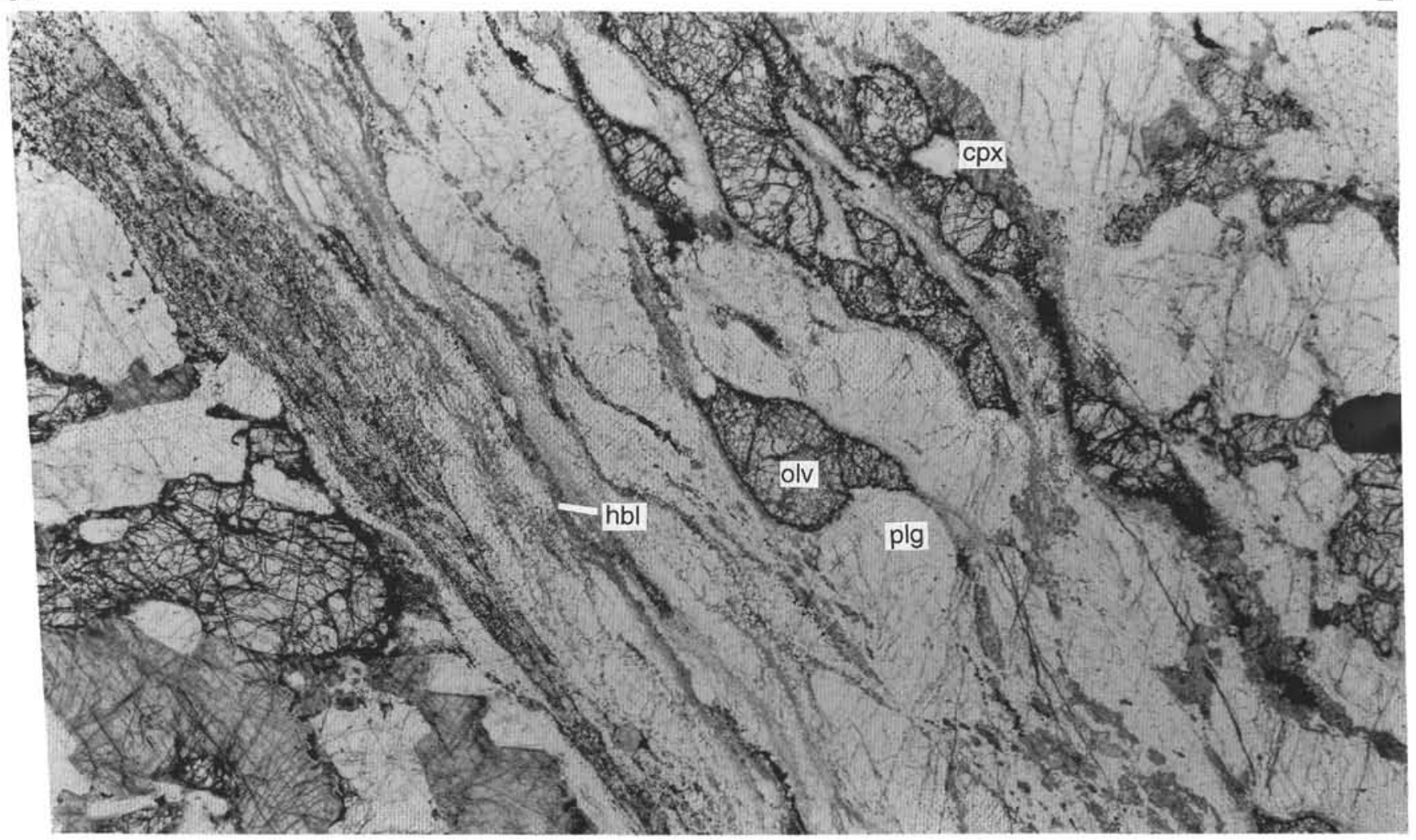

Figure 2. Photomicrograph of the discrete shear zone in Sample 153-922A-2R-4, 2-5 cm. Olv $=$ olivine, $\mathrm{cpx}=$ augite, $\mathrm{plg}=$ plagioclase, hbl $=$ hornblende. A-B depicts the profile line along which the microprobe point analyses in Figure 3 are done. Field of view is $3.2 \mathrm{~cm}$. 
153-922A-2R-04

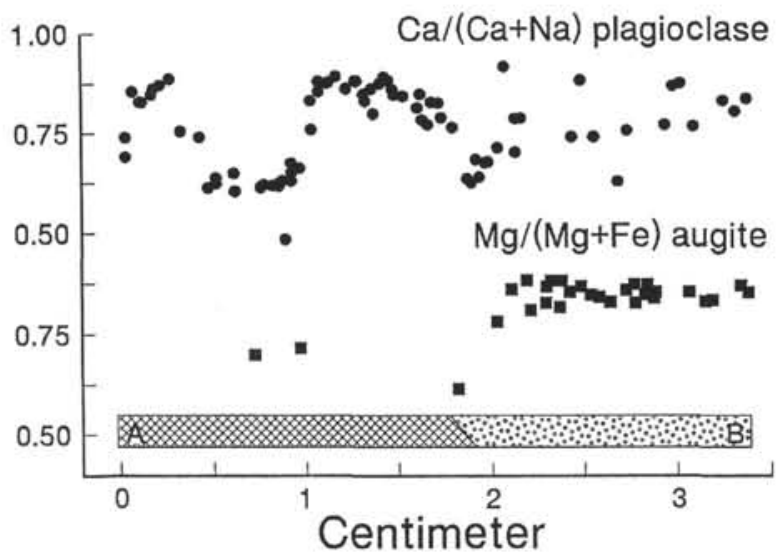

Figure 3. Compositional variation along profile A-B in Sample 153-922A$2 \mathrm{R}-4,2-5 \mathrm{~cm}$, showing the $\mathrm{Ca} /(\mathrm{Ca}+\mathrm{Na})$ and $\mathrm{Mg} /(\mathrm{Mg}+\mathrm{Fe})$ ratios for plagioclase and augite, respectively. Augite is dominantly replaced by brown hornblende within the left half of the shear zone. reminiscent of those of the discrete shear zones; however, there is no evidence for grain-scale crystal-plastic deformation within the vein and across the vein boundaries. The microgabbro consists of a finegrained, polygonal equigranular aggregate of augite and plagioclase and variable abundances of brown hornblende. Trains of equigranular augite grains define a weak banding within the vein, whereas albite twins in the plagioclase are aligned subparallel to each other. There is no significant change in the $\mathrm{Ca}$ to $\mathrm{Na}$ ratio of the plagioclase content and in the $\mathrm{Mg}$ number of the augite across the microgabbro vein and the vein-host rock boundaries (Fig. 6). However, the Ti/Al ratio of augite indicates high values $(0.62)$ caused by relatively high $\mathrm{Ti}$ but constant $\mathrm{Al}$ contents in the vein. This enrichment in $\mathrm{Ti}$ is independent of $\mathrm{Mg}$ number, suggesting that the microgabbro vein may represent injection of trapped melt into the gabbro and olivine gabbro host rock, rather than its crystallization from more evolved magmas.

\section{OVERVIEW OF METAMORPHISM AND ALTERATION IN THE GABBROIC ROCKS}

The gabbroic and associated plutonic rocks recovered at Sites 921-924 exhibit mineralogical and textural evidence for high-tem-

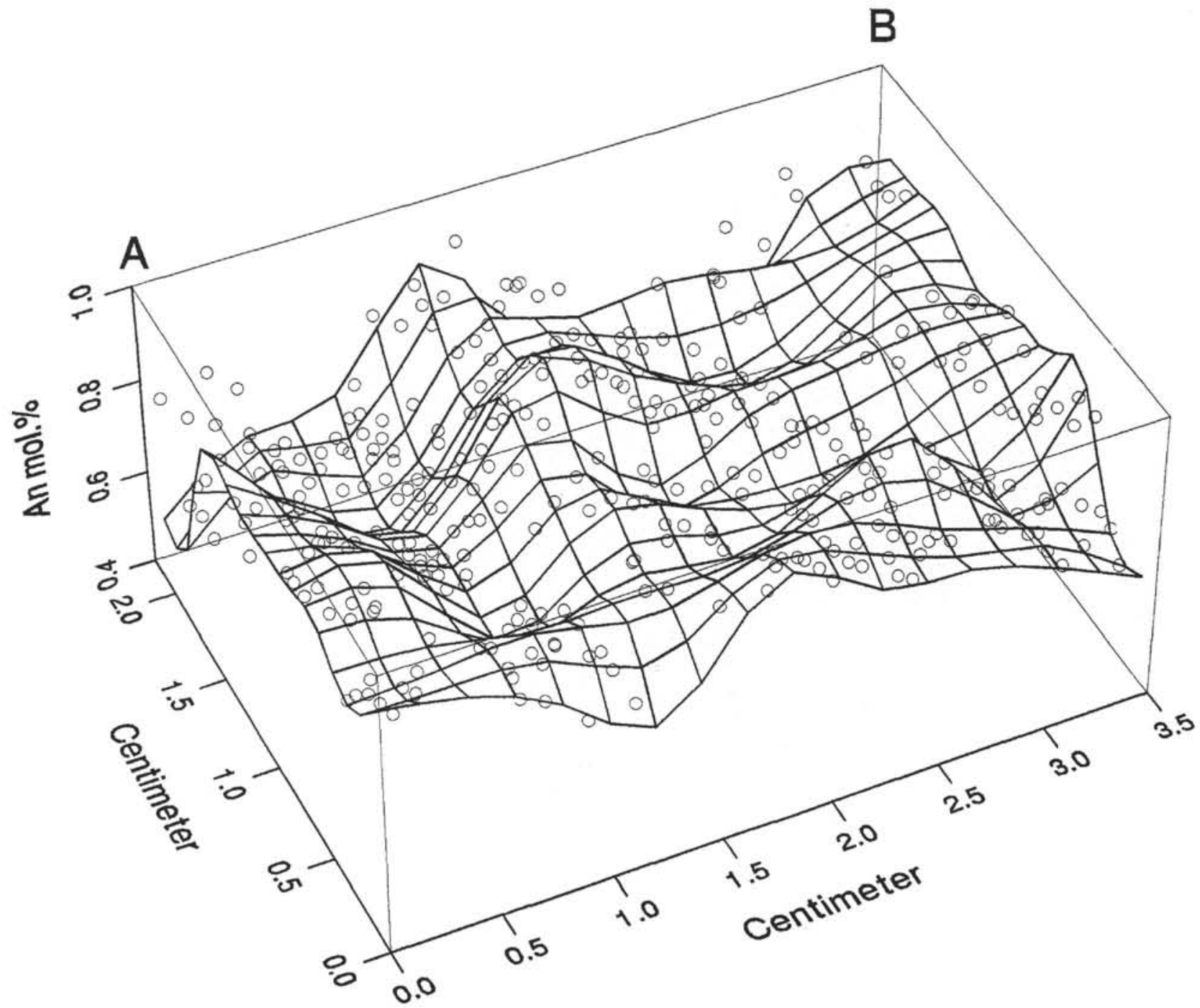

Figure 4. Compositional variation of the plagioclase across the discrete shear zone in Sample $153-922 \mathrm{~A}-2 \mathrm{R}-4,2-5 \mathrm{~cm}$. An mol\% is $\mathrm{Ca} /(\mathrm{Ca}+\mathrm{Na})$. A-B refers to the profile line shown in Figure 3 . The surface is the best fit to the data set, which consists of 350 separate point analyses. 
A

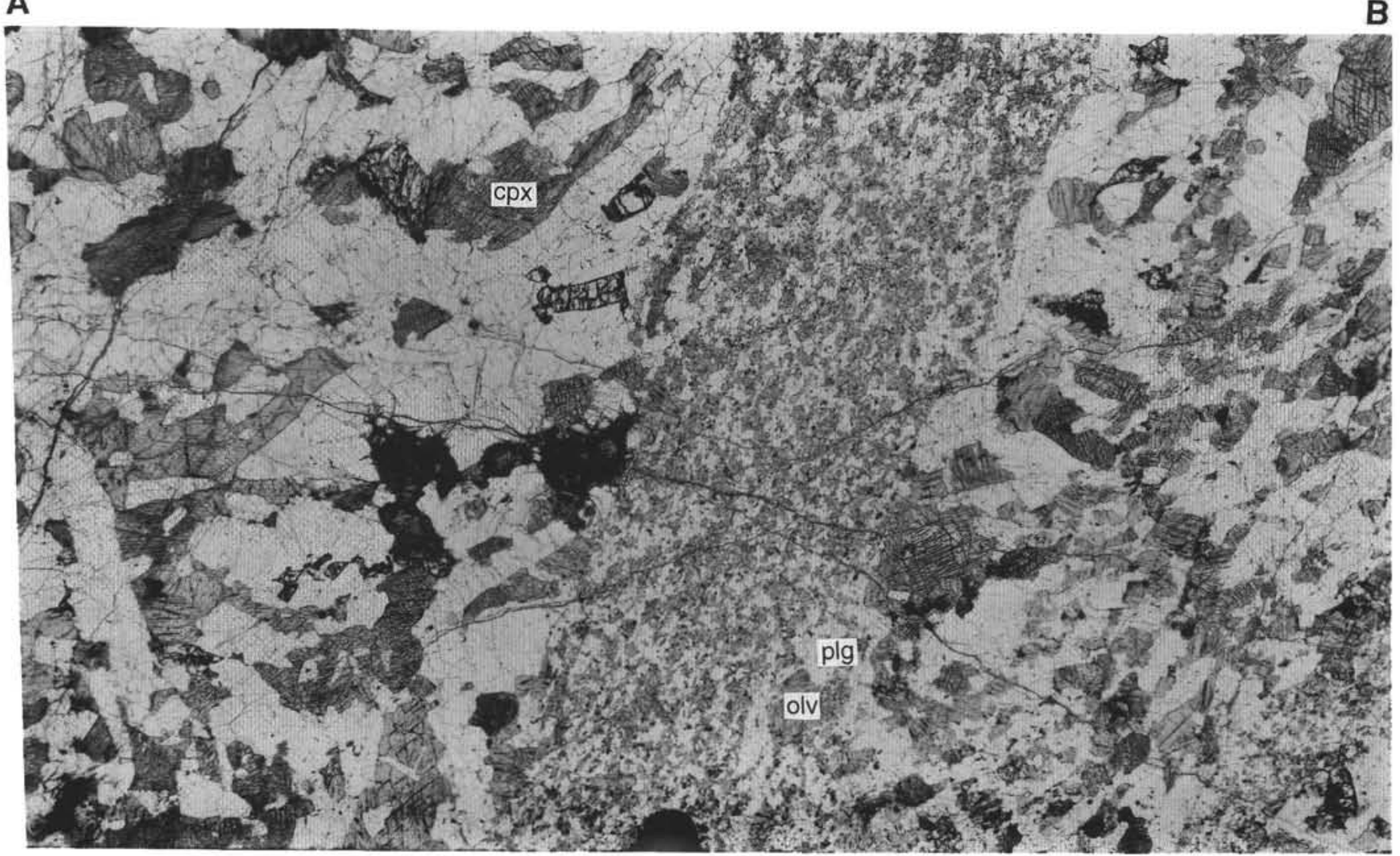

Figure 5. Photomicrograph of a microgabbro vein in Sample 153-923A-12R-2, 22-39 cm. Olv = olivine, $c p x=$ augite, plg = plagioclase. A-B depicts the profile line along which the microprobe point analyses in Figure 6 are done. Field of view is $3.2 \mathrm{~cm}$.

153-923A-12R-02

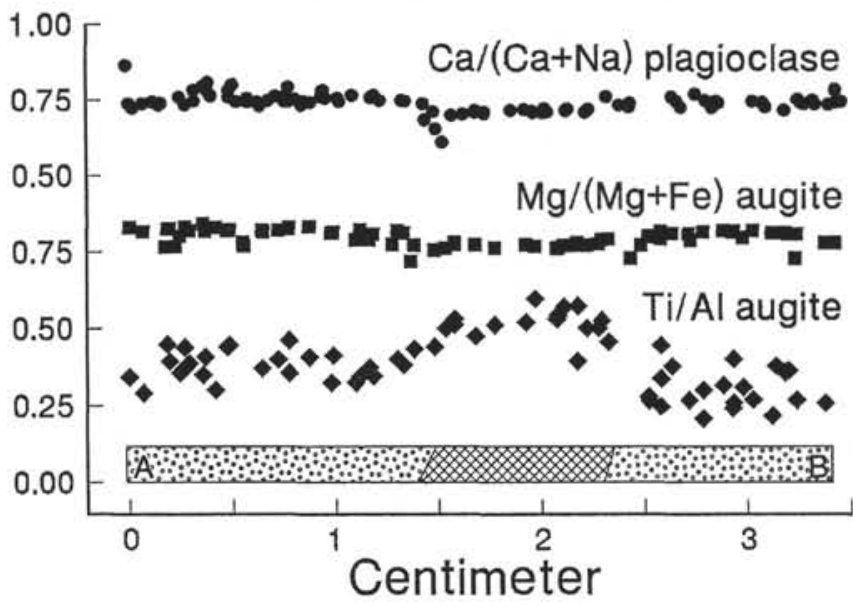

Figure 6. Compositional variation along profile A-B in Sample 153-923A$12 \mathrm{R}-2,22-39 \mathrm{~cm}$, showing the $\mathrm{Ca} /(\mathrm{Ca}+\mathrm{Na})$ and $\mathrm{Mg} /(\mathrm{Mg}+\mathrm{Fe})$ ratios for plagioclase and augite, respectively. The $\mathrm{Ti}$ to $\mathrm{Al}$ ratio of augite indicates high values within the vein, caused by relatively high $\mathrm{Ti}$ but constant $\mathrm{Al}$ contents.

perature hydration within discrete shear zones and localized pervasive alteration under amphibolite to greenschist metamorphic conditions in the host rock adjacent to veins and vein systems (Cannat, Karson, Miller, et al., 1995; Kelley, this volume). Porphyroclastic to gneissic textures and crystal-plastic foliation in discrete shear zones in Site 921-923 cores contain synkinematic amphibole and recrystal- lized olivine, plagioclase, and pyroxene, indicating that deformation and recrystallization occurred at temperatures $>700^{\circ} \mathrm{C}$, under amphibolite to transitional granulite facies metamorphic conditions (Liou et al., 1974; Spear, 1980; Kelley, this volume). Mylonitic to protomylonitic zones are characterized by anastomosing bands of fine- to very fine-grained neoblastic plagioclase, which commonly display a welldeveloped mosaic texture. The plagioclase bands are interlayered with anastomosing bands of hornblende and fine-grained oxide mineral stringers, which are locally overprinted by fine-grained actinolite and/or pargasitic hornblende. The hornblende-rich bands enclose porphyroclasts of olivine, aggregates of neoblastic fine-grained olivine, rounded to tapering porphyroclasts of clinopyroxene, and highly strained plagioclase grains. Retrograde alteration in these zones is commonly slight to moderate, with limited overprinting of actinolitetremolite, talc, and minor chlorite. Local mylonitic intervals are spatially associated with densely veined (actinolite and chlorite) and oxide-rich bands, which are generally overprinted by lower temperature secondary phases of talc, actinolite, and minor chlorite (Kelley, this volume).

Background static metamorphism of the gabbroic rocks away from the shear zones is heterogeneous and variable, both on a centimeter and several meter scale, reflecting variation in fracturing and attendant hydration (Cannat, Karson, Miller, et al., 1995; Kelley, this volume). Alteration intensities and occurrences of alteration minerals downhole and between holes at the same sites are broadly similar; a consistent variation with depth is absent. Interaction with the hydrothermal fluids resulted in static metamorphism under amphibolite to zeolite facies metamorphic conditions. In general, background alteration is governed by replacement of olivine, followed by clinopyroxene and orthopyroxene. The earliest alteration phases typically occur along grain boundaries and as fine veinlets within and around the 
grains, and they generally consist of fine-grained brown to pale green amphibole (Cannat, Karson, Miller, et al., 1995; Kelley, this volume).

Alteration associated with brittle deformation is most intense near veins and vein networks, within cataclastic deformation zones, and in felsic veins and their alteration halos in the adjacent host rock (Cannat, Karson, Miller, et al., 1995). Felted actinolitic mats and intergrown chlorite, with coronitic rims of chlorite after clinopyroxene, are most common in alteration halos associated with veins (Cannat, Karson, Miller, et al., 1995; Kelley, this volume). Secondary plagioclase with lesser amounts of actinolite, chlorite, epidote, prehnite, zeolite, and clay minerals replace the primary plagioclase adjacent to the hydrothermal veins and vein halos. Cataclastically deformed gabbroic rocks contain closely spaced shear zones (e.g., Sample 153921C-1W-1, Pieces 1-3), which are characterized by a submillimeter-scale banding parallel to the elongation of clasts of the gabbroic lithology and a high concentration of anastomosing, narrow $(<1 \mathrm{~mm})$ veinlets of actinolite, chlorite, epidote, prehnite, and clay minerals. Clinopyroxene and olivine are slightly to pervasively replaced by chlorite and actinolite along and near these veins, resulting in widespread static alteration in the cataclastic zones.

\section{DESCRIPTION OF VEIN ASSEMBLAGES}

The magmatic and crystal-plastic deformation fabrics in gabbroic rocks from Sites 921 to 924 are overprinted by several generations of vein assemblages and vein arrays. On the basis of vein-filling mineral compositions, vein assemblages are distinguished as felsic veins, amphibole veins, amphibole-chlorite-bearing veins, chlorite veins, and composite veins that contain two or more of the following minerals: chlorite, iron oxide/hydroxide, epidote, quartz, plagioclase, prehnite, and clay minerals. Vein assemblages and compositions of vein-filling minerals were identified through petrographic studies and electron microprobe analyses. The log of veins on hand sample scale for the Sites 921-924 cores, as published in Cannat, Karson, Miller, et al. (1995), was also used to locate the samples in the core and to determine the geometry, occurrence, and orientation of the studied veins and vein systems in the core reference frame. Crosscutting relations among more than two vein types are rare to absent in the core. However, the consistent crosscutting relations between different vein assemblages throughout cores from all four sites provide a relative vein chronology that is compatible with the metamorphic history of the gabbroic rocks (Kelley, this volume).

\section{Felsic Veins}

These veins occur as submillimeter to cm-scale, planar to irregular veins with sharp to diffuse boundaries that crosscut deformation fabrics (foliation and/or lineation) and primary igneous textures in the rocks (Fig. 7). They commonly have moderately to well-developed alteration halos and contain plagioclase, quartz, minor hydrothermal clinopyroxene, and accessory phases such as oxide minerals, apatite, and zircon (Cannat, Karson, Miller, et al., 1995; Kelley, this volume). Actinolite, chlorite, epidote, and clay minerals occur as secondary minerals after clinopyroxene and plagioclase. Locally, felsic
A

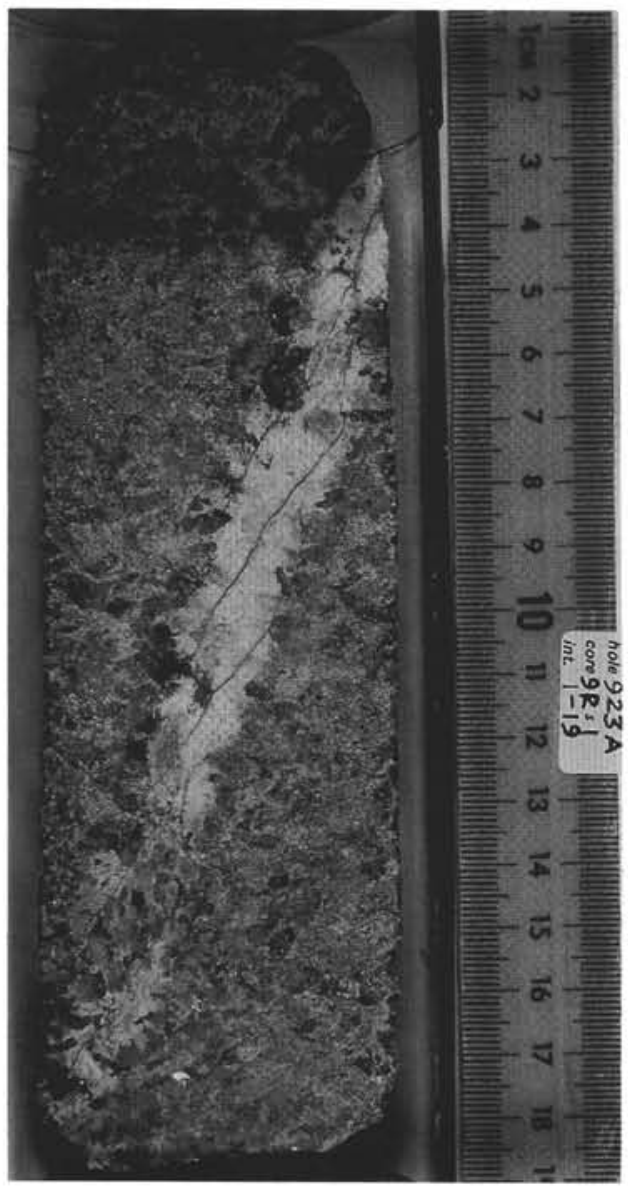

B

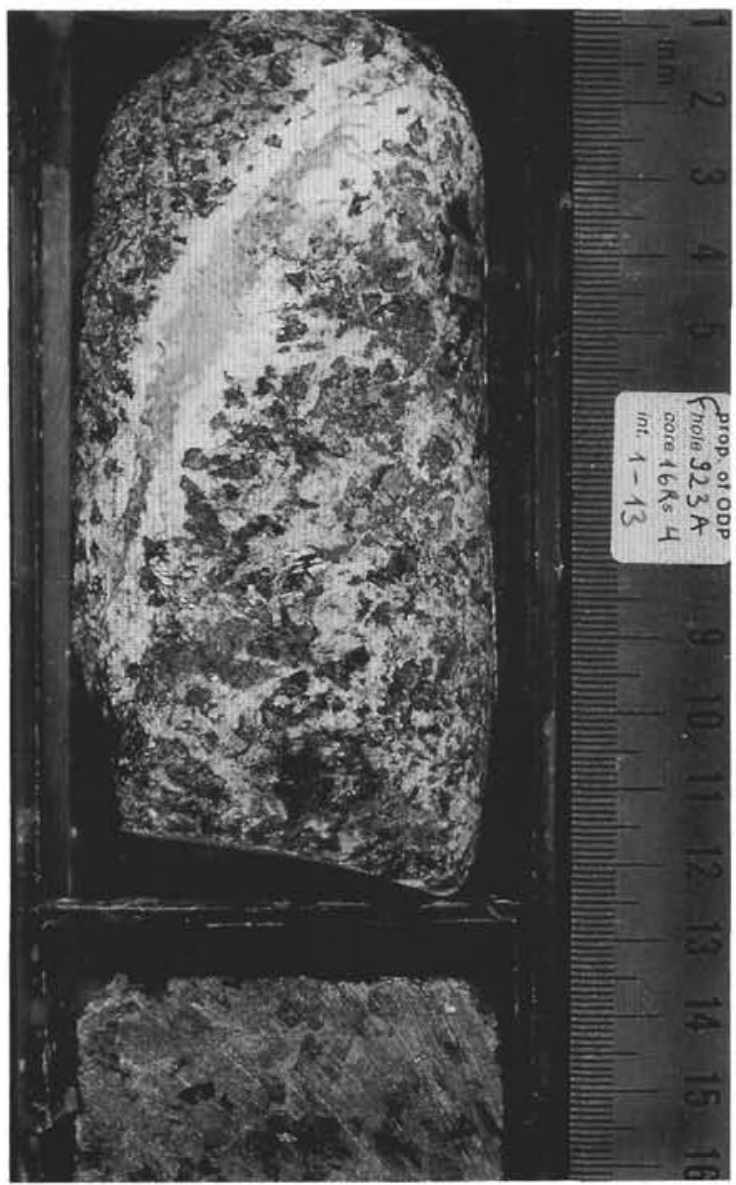

Figure 7. A. Felsic vein in a medium- to coarse-grained olivine gabbro (Sample 153-923A-9R-1, 1-19 cm). B. Felsic vein replaced by chlorite in the center and secondary plagioclase along the margins. Back of the archive half of Sample $153-923 \mathrm{~A}-16 \mathrm{R}-4,1-13 \mathrm{~cm}$. 
veins are cut by intravein amphibole-chlorite veins and veinlets (e.g., Sample 153-923A-9R-1, 1-19 cm) or are extensively replaced by chlorite in their core and altered plagioclase at their margins (e.g., Sample 153-923A-16R-4, 1-13 cm; Fig. 7). In general, felsic veins are cut across by amphibole-chlorite veins. Some felsic veins are sheared along their margins and display evidence of grain-size reduction in the wall rock adjacent to their sheared boundaries (e.g., Sample 153-922A-2R-2, Piece 1). The majority of felsic veins have either subhorizontal $\left(2^{\circ}-20^{\circ}\right)$ or subvertical $\left(72^{\circ}-80^{\circ}\right)$ dip angles, although subhorizontal ones are more common (Samples 153-921E-4R-1, Pieces 1 and 6; 6R-2, Piece 1; and 923A-16R-4, Piece 4).

\section{Amphibole Veins}

Nearly a third of the hydrothermal veins at Sites 921-924 are monomineralic amphibole veins that occur as either single veins with planar boundaries, or as anastomosing branches of veins and veinlets and subparallel vein arrays. The dominant vein-filling amphibole minerals are actinolite, tremolite, and several different hornblende types (Table 1). Amphibole veins occur most commonly in foliated and sheared gabbros crosscutting gneissic and mylonitic foliations at high angles (Figs. 8, 9; Samples 153-923A-16R-2, 41-46 cm; 2R-2, $66-74 \mathrm{~cm} ; 2 \mathrm{R}-2,33-36 \mathrm{~cm}$; and 922A-2R-2, 68-71 cm), and they generally have moderate to steep dip angles. Some amphibole veins are concentrated within and along discrete shear zones and form two subsets that are nearly perpendicular to each other. A subset of subparallel amphibole veins occur at shear zone boundaries and within shear zones and may alternate with recrystallized plagioclase bands (i.e., Sample 153-922A-2R-5, 39-45 cm; and 2R-5, 116-125 cm). A second subset of amphibole veins forms subparallel and en echelon vein segments that are both cut by and cut the shear zone-parallel first vein set. These mutual crosscutting relationships between the two perpendicular vein sets in the vicinity of the discrete shear zones indicate that the orthogonal vein assemblages are coeval and that they are associated with the crack and microfracture systems along and near the shear zones.

Some amphibole veins result from simple crack filling, and they do not display any evidence for shearing and displacement along and across their boundaries. In some single veins, hornblende shows well-developed crystals with rhombic cleavages (e.g., Sample 153921B-4R-1, 129-135 cm). In general, amphibole veins do not display internal fabrics or textures resulting from stress-induced crystallization. Some veins have associated alteration halos containing secondary plagioclase and/or clinopyroxene (Fig. 10A); secondary plagioclase is albitic $\left(\mathrm{An}_{14}-\mathrm{An}_{17}\right)$, whereas secondary (hydrothermal?) clinopyroxene is poor in $\mathrm{Al}$ and $\mathrm{Cr}$ compared to the primary pyroxene in the host rock. Host rock mineralogy along the vein margins may control the composition of amphibole developed within the veins, such as brown hornblende occurring along the inner walls adjacent to clinopyroxene crystals in the host rock, in contrast to green hornblende (actinolite) developing where the host rock mineral along the vein wall is dominated by plagioclase (Sample 153-921B-4R-01, $129-135 \mathrm{~cm}$; Fig. 10B).

\section{Amphibole-Chlorite Veins}

Amphibole-chlorite-bearing veins are common in cores from all four sites and generally occur as discrete veins in all rock types. The most common amphibole mineral in these composite veins is actinolite (Table 1; Sample 153-924B-5R-1, 34-40 cm). Amphibole-chlorite veins commonly have planar geometry with sharp to diffuse boundaries with the host rock (Fig. 11) and locally form anastomosing networks of branching veins and veinlets. In some samples, they have associated symmetric, millimetric to submillimetric alteration halos (Samples 153-921C-2R-3, Piece 8, and 3R-1, Piece 9). Amphibole-chlorite veins also occur as conjugate sets of subperpendicular vein systems (i.e., Samples 153-922A-1R-1, Piece 4A; 923A-
10R-3, Piece 5; 921D-2R-1, Piece 10); in general, subhorizontal veins intersect and crosscut the subvertical (in the core reference frame) veins.

Amphibole-chlorite veining takes several forms. They may form regular to irregular arrays of filled microcracks and veinlets that display different geometries when crosscutting olivine and clinopyroxene grains (Fig. 12A). In some samples, these intracrystal vein networks may crosscut grain boundaries and continue across the adjacent crystals or the enclosing recrystallized matrix. Some amphibolechlorite veins crosscut foliation and/or lineation at oblique to high angles (Samples 153-921B-1W-2, Piece 4, 2R-1, Pieces 5, 8, and 9, and $2 \mathrm{R}-2$, Pieces 1,2 , and 5-8) and may also cut the discrete shear zones at moderate to high angles (Fig. 12B; Samples 153-922A-2R-5, Piece 2A; 923A-16R-2, Piece 2; 924C-6R-1, Piece 7). For example, an actinolite-chlorite vein in Sample 153-924C-6R-1 (Piece 7) crosscuts a $5 \mathrm{~mm}$-wide and steeply dipping fault and is in turn cut by two, nearly orthogonal veinlets composed of epidote and clay minerals. However, some actinolite-chlorite veins are cut and offset along faults by as much as several millimeters (e.g., Sample 153-923A-5R-1, Piece 2), indicating mutual crosscutting relationships between this vein generation and the brittle faults. Some actinolite-chlorite veins crosscut the monomineralic amphibole veins within and along discrete shear zones (e.g., Sample 153-923A-16R-2, 41-46 cm), whereas others occur with recrystallized plagioclase in submillimetric shear zones (Fig. 12C; Sample 153-923A-16R-4, 38-44 cm). Other actinolite-chlorite veins are spatially associated with discrete shear zones that locally correspond to lithological and/or textural boundaries in the host rock (Samples 153-922A-3R-1, Piece 4; 922B-2R-3, Piece 1). In Sample 922A-3R-1 (Piece 4A), for example, a network of actinolite-chlorite veins is concentrated along a subvertical anastomosing shear zone that separates troctolite from olivine gabbro. Actinolite-chlorite veins are also common within and along cataclastic zones where densely distributed microfractures and fracture networks are associated with grain-size reduction and intense alteration in gabbroic rocks. Anastomosing actinolite-chlorite veins and veinlets in these zones dissect the grains with no apparent offset (Samples 153-922A-3R-1, Pieces 3 and 4; 923A-15R-1, Pieces 5-14; and 924C-2R-1, Piece 6).

Almost all amphibole-chlorite veins occur as pure extensional cracks with wall-perpendicular fibers. Clinopyroxene, plagioclase, and olivine grains are cut by these veins with no apparent lateral offset. Locally, some veins contain fragments of the wallrock aligned parallel to vein walls (Fig. 12B; Sample 153-923A-16R-2, 41-46 $\mathrm{cm}$ ) indicating incremental opening of the cracks. In some actinolitechlorite vein networks, actinolite fibers are preferentially aligned along the inner walls bounding hornblende overgrowths on the clinopyroxene grains in the host rock (Fig. 12C). Similarly, chlorite is predominant in certain segments of some actinolite-chlorite veins in which the minerals along the vein walls consist mainly of plagioclase (e.g., Sample 153-923A-2R-2, 66-74 cm). This syntaxial overgrowth of vein-filling minerals indicates that the composition of the wallrock mineral(s) may control the type of vein-filling minerals in these veins. In some veins, chlorite occurs as wall-perpendicular fibers along the inner wall, whereas actinolite is present in the core of the veins (e.g., Sample 153-924C-7R-1, 46-52 cm; Fig. 12D); in other veins, the core is composed of chlorite with actinolite only along the inner walls (i.e., Samples 153-921E-8R-1, 74-80 cm; 921D-5R-1, $73-81 \mathrm{~cm})$.

Amphibole-chlorite-bearing veins crosscut felsic veins (e.g., Sample 153-922B-1W-1, 92-104 cm) and discrete shear zones containing amphibole veins (e.g., Sample 153-923A-16R-2, 41-46 cm), but they are crosscut by epidote-bearing composite veins (Fig. 12D; Samples 153-922A-2R-3, Piece 3; 924C-7R-1, 46-52 cm). A steeply dipping aragonite-chlorite vein also cuts across an actinolite-chlorite vein in Sample 153-921D-3R-1 (Piece 7). Some composite veins consisting of chlorite, clay, and oxide minerals form branching and anastomosing arrays of veinlets that occur with actinolite-chlorite veins (e.g., Sample 153-923A-7R-1, Piece 2A). These crosscutting 
Table 1. Mineralogy, texture, abundance, and host-rock assemblages of representative hydrothermal veins and vein systems in gabbroic rocks from Sites 921 to 924 , MARK area.

\begin{tabular}{|c|c|c|c|c|}
\hline $\begin{array}{l}\text { Core, section, } \\
\text { interval }(\mathrm{cm})\end{array}$ & Vein assemblage & Vein textures & Vein abundance in thin section* & Groundmass assemblage \\
\hline \multicolumn{5}{|l|}{ 153-921B- } \\
\hline $4 \mathrm{R}-1,80-84$ & $\begin{array}{l}\text { Actinolitic amphibole + sodic plg }\left(\mathrm{An}_{14^{-}}\right. \\
\left.\qquad A n_{17}\right)+c p x\end{array}$ & $\begin{array}{l}\text { Vein is sheared; amphiboles are elongate } \\
\text { and at a low angle to the vein walls. }\end{array}$ & One, mm-scale vein. & $\begin{array}{l}\text { olivine }\left(\mathrm{Fo}_{77}\right)+\mathrm{cpx}(\mathrm{Mg} \#=0.86) \\
\quad+\operatorname{plg}\left(\mathrm{An}_{6 \mathrm{~T}}-\mathrm{An}_{71}\right)\end{array}$ \\
\hline $4 \mathrm{R}-1,129-135$ & $\begin{array}{l}\text { Monomineralic amphibole (actinolite-hbl) } \\
\text { + zircon; plg near vein is more sodic than } \\
\text { primary plg + late chlorite }\end{array}$ & $\begin{array}{l}\text { Blue-green amph in vein center, brown } \\
\text { amph along vein walls; very coarse } \\
\text { grained. }\end{array}$ & One, thick, mm-scale vein. & $\begin{array}{l}\operatorname{plg}\left(\mathrm{An}_{50}\right)+\mathrm{cpx}(\mathrm{Mg} \#=82-88) \\
\text { partially replaced by amphibole. }\end{array}$ \\
\hline \multicolumn{5}{|l|}{ 153-921D- } \\
\hline 2R-1, 94-99 & $\begin{array}{l}\text { Monomineralic chlorite }(\mathrm{Mg} \# 40) \text {, chlorite }+ \\
\text { quartz, monomineralic qtz }+ \text { trace } \\
\text { carbonate }\end{array}$ & $\begin{array}{l}\text { Cross-fiber chlorite, mostly perpendicular } \\
\text { to the vein walls, but some are diagonal } \\
\text { (locally). }\end{array}$ & $\begin{array}{l}\text { Moderate abundance of } 10-\text { to } \\
20-\mu \text { m-thick veins. }\end{array}$ & $\mathrm{plg}+\mathrm{cpx}$ \\
\hline $5 R-1,73-81$ & Monomineralic chlorite & $\begin{array}{l}\text { Mostly cross-fiber chlorite in subparallel } \\
\text { veins. }\end{array}$ & $\begin{array}{l}\text { Moderate abundance of } 10-\text { to } \\
20-\mu \text { m-thick veins, and } \\
\text { numerous tiny veinlets. }\end{array}$ & $\mathrm{plg}+\mathrm{cpx}$ \\
\hline \multicolumn{5}{|l|}{ 153-921E- } \\
\hline $8 \mathrm{R}-1,74-80$ & $\begin{array}{l}\text { Blue-green amph }+ \text { chlorite (mostly } \\
\text { chlorite) }\end{array}$ & $\begin{array}{l}\text { Randomly oriented crystals; amph in } \\
\text { patches. }\end{array}$ & Abundant. & $\mathrm{plg}+\mathrm{cpx}$ \\
\hline \multicolumn{5}{|l|}{$153-922-$} \\
\hline $2 \mathrm{R}-2,68-71$ & Blue-green amph + chlorite & $\begin{array}{l}\text { Randomly oriented crystals; some grow } \\
\text { beyond vein walls, giving veins a } \\
\text { "fuzzy" appearance. }\end{array}$ & $\begin{array}{l}\text { Very abundant; mostly } \\
\text { subparallel but some } \\
\text { crosscutting. }\end{array}$ & $\begin{array}{l}\text { plg }+\mathrm{cpx} \text { (rock is highly altered, } \\
\text { and cpx is almost entirely } \\
\text { replaced by amphibole). }\end{array}$ \\
\hline $2 \mathrm{R}-5,39-45$ & $\begin{array}{l}\text { Blue-green amph } \pm \text { chlorite; actinolite core } \\
\text { and pargasitic hbl rim }\end{array}$ & $\begin{array}{l}\text { Randomly oriented amphibole in the } \\
\text { vein. }\end{array}$ & Abundant. & $\mathrm{plg}+\mathrm{cpx}$ \\
\hline $2 \mathrm{R}-5,112-120$ & Blue-green amph + chlorite & $\begin{array}{l}\text { Cross-fiber chlorite perpendicular to vein } \\
\text { wall; amph random. }\end{array}$ & Moderate abundance. & $\mathrm{plg}+\mathrm{cpx}$ \\
\hline $2 \mathrm{R}-5,116-125$ & Blue-green amph + chlorite & Fine- to medium-grained. & $\begin{array}{l}\text { Abundant, crosscutting } \\
\text { generations. }\end{array}$ & $\mathrm{plg}+\mathrm{cpx}$ \\
\hline \multicolumn{5}{|l|}{$153-923 \mathrm{~A}-$} \\
\hline $2 \mathrm{R}-2,33-36$ & Hornblende (brown to dark green) + chlorite & Coarse hbl dominates veins. & $\begin{array}{l}\text { Moderate abundance; tens of } \\
\text { microns wide. }\end{array}$ & $\mathrm{plg}+\mathrm{cpx}$ \\
\hline $2 \mathrm{R}-2,66-74$ & $\begin{array}{l}\text { Actinolitic amph + chlorite amph relatively } \\
\text { coarse }\end{array}$ & "Stripe" of subparallel veins. & & $\mathrm{plg}+\mathrm{cpx}$ \\
\hline $8 R-2,76-82$ & Actinolitic amph & $\begin{array}{l}\text { Fine- to medium-grained; no internal } \\
\text { fabric. }\end{array}$ & $\begin{array}{l}\text { Two submillimetric, } \\
\text { anastomosing and branching } \\
\text { veins. }\end{array}$ & $\mathrm{plg}+\mathrm{cpx}$ \\
\hline ISR-3, 80-85 & Discontinuous chlorite veinlets & Fine-grained. & Moderate to abundant. & $\mathrm{plg}+\mathrm{cpx}$ \\
\hline $16 R-2,41-46$ & Chlorite + clinopyroxene & Shear zones; curving chlorite crystals. & $\begin{array}{l}\text { Abundant veins and veinlets; } \\
\text { thicker veins at high angle to } \\
\text { veinlets. }\end{array}$ & $\mathrm{plg}+\mathrm{cpx}$ \\
\hline $16 R-4,38-44$ & Chlorite + epidote + amph + plagioclase & $\begin{array}{l}\text { Amph zoned (dark green core, pale green } \\
\text { rim), also patches of brown-green } \\
\text { amph; chl mostly perpendicular to vein } \\
\text { wall, but curving where vein } \\
\text { intersected by shear zone. }\end{array}$ & $\begin{array}{l}\text { Moderate abundance; in some } \\
\text { places, multiple vein } \\
\text { generations occupying same } \\
\text { location: several nearby } \\
\text { cross-fiber chlorite zones } \\
\text { surrounded by later chlorite; } \\
\text { individual chl crystals are } \\
\text { folded where vein intersected } \\
\text { by a shear zone. }\end{array}$ & $\begin{array}{l}\mathrm{plg}+\mathrm{cpx} \text { (with thick actinolite } \\
\text { rims). }\end{array}$ \\
\hline \multicolumn{5}{|l|}{$153-923 \mathrm{~A}-$} \\
\hline $16 \mathrm{R}-4,79-85$ & Chlorite & Cross-fiber chlorite. & $\begin{array}{l}\text { Moderate abundance, } \\
\text { subparallel arrays. }\end{array}$ & $\mathrm{plg}+\mathrm{cpx}$ \\
\hline \multicolumn{5}{|l|}{ 153-924B- } \\
\hline $5 R-1,34-40$ & Chlorite + actinolitic amph & $\begin{array}{l}\text { Two generations, one offset slightly by } \\
\text { other; older veins are mostly fine- } \\
\text { grained amph + chl; later veins has } \\
\text { amph in center (elongate parallel to } \\
\text { vein direction) and cross-fiber } \\
\text { (perpendicular) chl at vein walls. }\end{array}$ & Moderate abundance. & $\mathrm{plg}\left(\mathrm{An}_{64}\right)+\mathrm{cpx}(\mathrm{Mg} \#=52)$ \\
\hline \multicolumn{5}{|l|}{$153-924 \mathrm{C}$ - } \\
\hline $6 \mathrm{R}-1,31-39$ & Na zeolite + chlorite + pargasitic amphibole & $\begin{array}{l}\text { Cross-fiber, tapering vein; zeolite } \\
\text { postdates chlorite + amph (amph in } \\
\text { center, chl at margins). }\end{array}$ & $\begin{array}{l}\text { One, tapering vein; } 1 \mathrm{~mm} \text { wide } \\
\text { at widest. }\end{array}$ & olivine $+\operatorname{cpx}+$ plg \\
\hline \multicolumn{5}{|l|}{$153-924 \mathrm{C}$} \\
\hline $7 \mathrm{R}-1,124-132$ & Zeolite + chlorite & Cross-fibers; zeolite postdates chl. & One, thick vein ( $2 \mathrm{~mm}$ wide). & olivine + cpx + plg \\
\hline $7 \mathrm{R}-1,46-52$ & $\begin{array}{l}\text { Actinolite- } \mathrm{hbl}+\mathrm{Mg} \text { chlorite }+\mathrm{cpx}+ \\
\text { epidote }\end{array}$ & $\begin{array}{l}\text { Cross-fiber chlorite at margins of coarse- } \\
\text { grained vein; randomly oriented green } \\
\text { to blue-green amph; crosscuts thick } \\
\text { vein or randomly oriented actinolite } \\
\text { and fine-grained minerals. }\end{array}$ & Abundant. & cpx + plg \\
\hline
\end{tabular}

Notes: $*=$ "abundance" descriptions are semiquantitative, and refer to moderate $(\approx 10$ noticeable veins); abundant $(\approx 20$ veins); and very abundant $(\approx 20$ veins) in the thin section. Amph $=$ amphibole, $\mathrm{chl}=$ chlorite, $\mathrm{cpx}=$ clinopyroxene, $\mathrm{hbl}=$ hornblende, $\mathrm{plg}=$ plagioclase, $\mathrm{qtz}=$ quartz. 


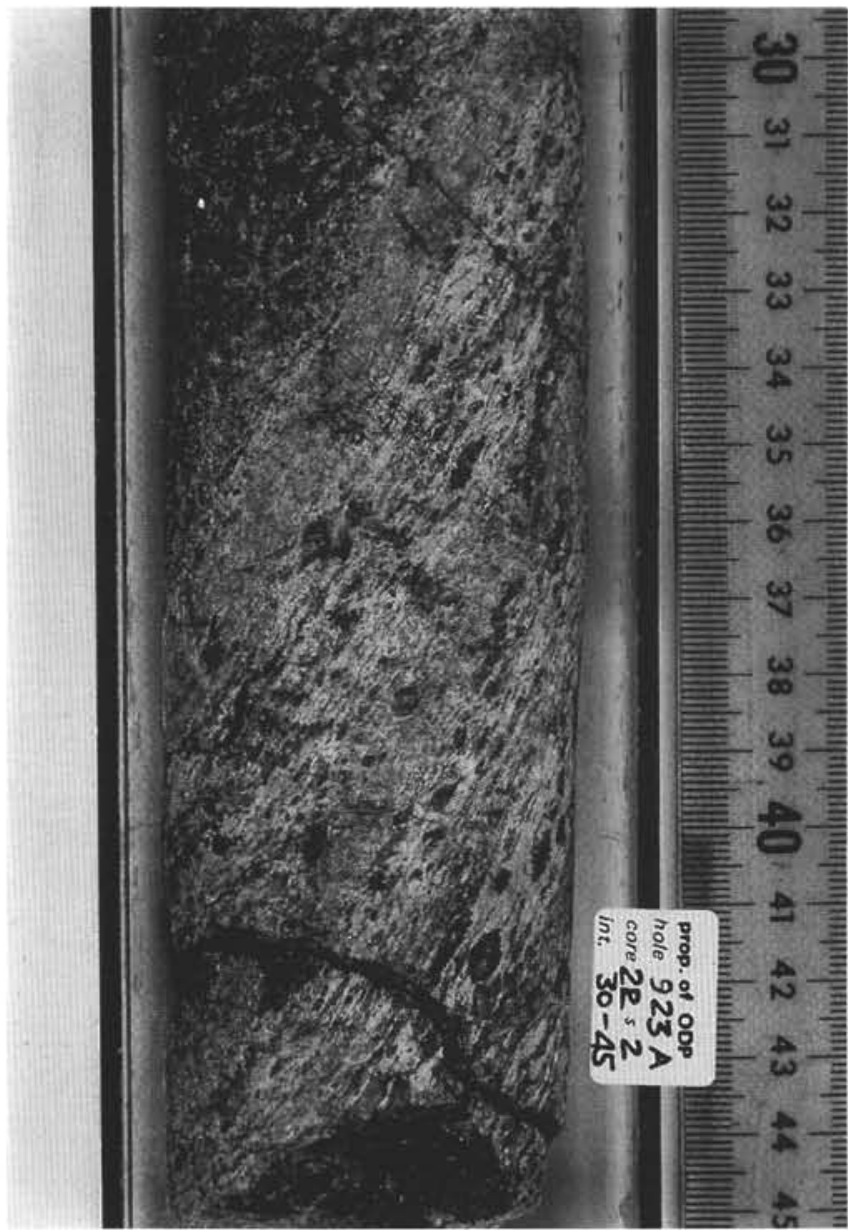

Figure 8. Subparallel amphibole veins crosscutting at high angles the foliation/lineation in a porphyroclastic gabbro (Sample 153-923A-2R-2, 30-45 $\mathrm{cm})$.

relations indicate that amphibole-chlorite veins postdate felsic and amphibole veins, but predate composite veins composed of epidote, chlorite, quartz, clay and/or oxide minerals.

\section{Chlorite Veins}

Chlorite veins occur in all gabbroic lithologies recovered at Sites 921-924, and are commonly found together with amphibole-chlorite veins in the same core sections (Table 1). In hand samples, they are distinguished from amphibole-chlorite veins by their dark green color and associated yellow-brown colored alteration halos (Fig. 13); in thin section, they are composed predominantly of chlorite, with trace amounts of prehnite and/or clay minerals. Chlorite veins are generally planar with sharp boundaries, and locally form anastomosing veinlets that crosscut magmatic textures, and clinopyroxene and plagioclase grains with no apparent lateral offset or displacement (Fig. 14A). Conjugate sets of chlorite veins in some sections form orthogonal vein networks (i.e., Sample 153-923A-15R-3, 38-45 cm; 924B$5 \mathrm{R}-1,34-40 \mathrm{~cm}$ ). The majority of chlorite veins have moderate to steep dips in the core.

Similar to the actinolite-chlorite veins, chlorite veins take several different forms; they form intragrain hairline microveinlets in clinopyroxene and plagioclase (Fig. 14A) and subparallel vein arrays crosscutting discrete shear zones, deformation bands, and foliation/ lineation at oblique to high angles (i.e., Samples 153-923A-16R-2,
41-46 cm; 16R-4, 06-12 cm). In Sample 153-923A-16R-4 (Piece 1), submillimetric $(0.5$ to $0.25 \mathrm{~mm})$ chlorite veins cut a 0.9 -mm-wide shear zone, which separates a coarse-grained undeformed gabbro from a finer grained, foliated metagabbro. A second set of subparallel chlorite veins within the foliated gabbro occurs parallel to the shear zone. An anastomosing network of irregular chlorite veins is concentrated in the footwall of a 0.5 -mm-wide fault zone in gneissic olivine gabbro in Sample 153-923A-16R-4 (Piece 8, 79-85 cm). This steeply dipping $\left(68^{\circ}\right)$ fault zone is associated with grain-size reduction in plagioclase, truncation of clinopyroxene grains, and alignment of ironoxide stringers; the plastic fabric (foliation and lineation) in the gneissic gabbro displays downward drag approaching the fault zone, suggesting a normal sense of movement along the fault. Chlorite veins are parallel to the fault trace, but show no lateral offset or displacement. Wall-perpendicular chlorite fibers in these veins indicate that they fill pure extensional cracks.

In general, all chlorite in these veins display a wall-perpendicular fibrous habit (Fig. 14B). In addition, some chlorite veins may include multiple bands of chlorite in their cores that are parallel to the vein walls (Fig. 14C). This internal fabric, together with the existence of stringers of host-rock fragments within the veins, is characteristic of crack-seal veins, which imply incremental and multiple episodes of vein opening (Ramsay and Huber, 1983). Locally, chlorite veins are reactivated by iron oxide/hydroxide-bearing veins, which partially replace chlorite in the center of the veins (Fig. 14D).

\section{Composite Veins}

These veins form late populations and consist of various hydrous minerals. Epidote-bearing composite veins occur as narrow (1-2 $\mathrm{mm}$ ), single veins commonly with en echelon segments that display widely varying orientations, although they commonly exhibit moderate to subvertical dip angles. They contain plagioclase, quartz, prehnite, in addition to epidote, and in some cases clay mineral-rich assemblages occur along their margins (e.g., Sample 153-922B-2R-1, Pieces $1 \mathrm{~A}$ and $1 \mathrm{~B})$. They cut shear zones and crystal-plastic fabrics at high angles (i.e., Samples 153-922B-2R-1, Pieces 1A and 1B; 922A2R-4, Piece 2B; 922A-2R-5, 39-45 cm), and crosscut amphibolechlorite veins at oblique to high angles (i.e., Samples 153-922A-2R3, Piece 3; 924C-7R-1, 46-52 cm; Fig. 12D). In Sample 153-923AIW-1 (Piece 2), a 2-mm-thick epidote-plagioclase vein cuts and offsets a 1-mm-thick actinolite-chlorite vein. Epidote-bearing veins are associated with intense wallrock alteration, which involves pervasive replacement of plagioclase by epidote, prehnite, and secondary plagioclase (Table 1).

Chlorite \pm plagioclase \pm quartz-bearing composite veins form rare subvertical veins in cores from Sites 921 to 924 . Some of these veins show an internal fabric characterized by alternating diagonal bands of chlorite and quartz (Fig. 15A; Sample 153-921D-2R-1, 94-99 cm). However, there is no shearing or lateral offset of grains along these veins. They are in places crosscut by subhorizontal (in the core reference frame) monomineralic quartz veins (Fig. 15B; Sample 153921D-2R-1, 94-99 cm).

Some composite veins are composed of chlorite and/or iron oxide/ hydroxide, prehnite, and talc in addition to clay minerals. These veins are more irregular in their morphology and distribution than the other vein generations and form single veins and/or vein networks. They locally show en echelon and overlapping segments, wrap around grain boundaries, and overprint and reactivate chlorite veins (e.g., Sample 153-923A-16R-4, 79-85 cm; Fig. 14D). In places, the dip of individual veins changes from subhorizontal to subvertical in short intervals, and in some cases the mineralogy changes along their length depending on the mineral composition of the host rock (i.e., Samples 153-924C-6R-1, Piece 2, and 7R-1, 124-132 cm). In Sample 153-924C-3R-1, 38-44 cm, for example, several submillimetric 
A

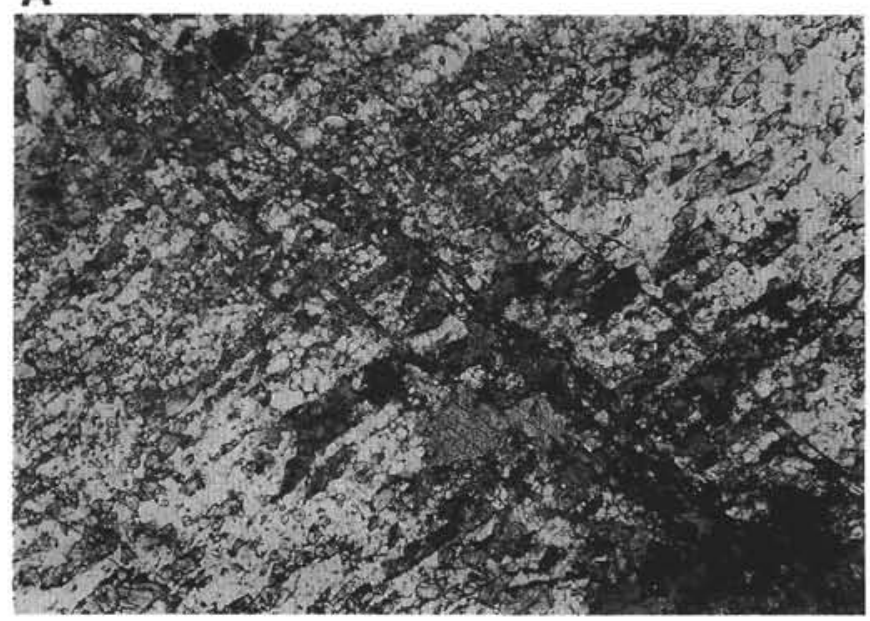

C

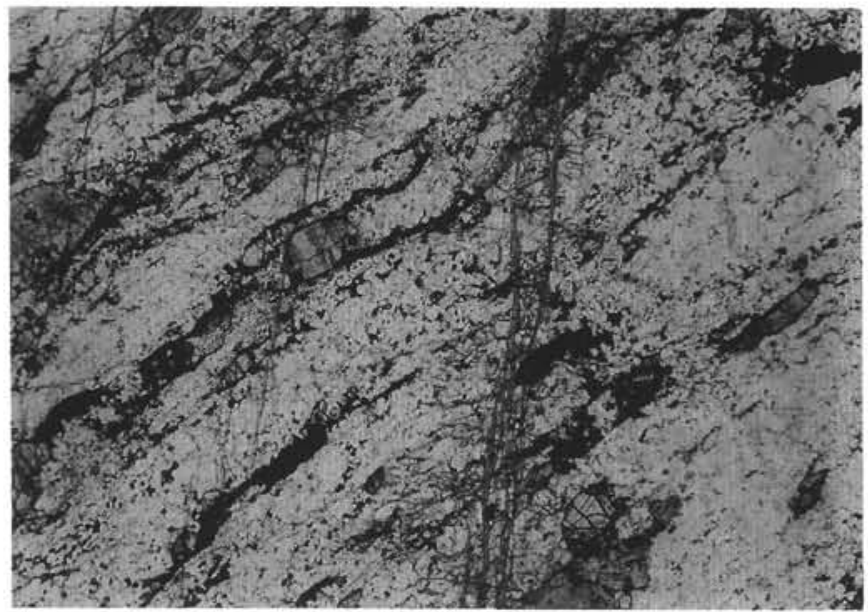

B

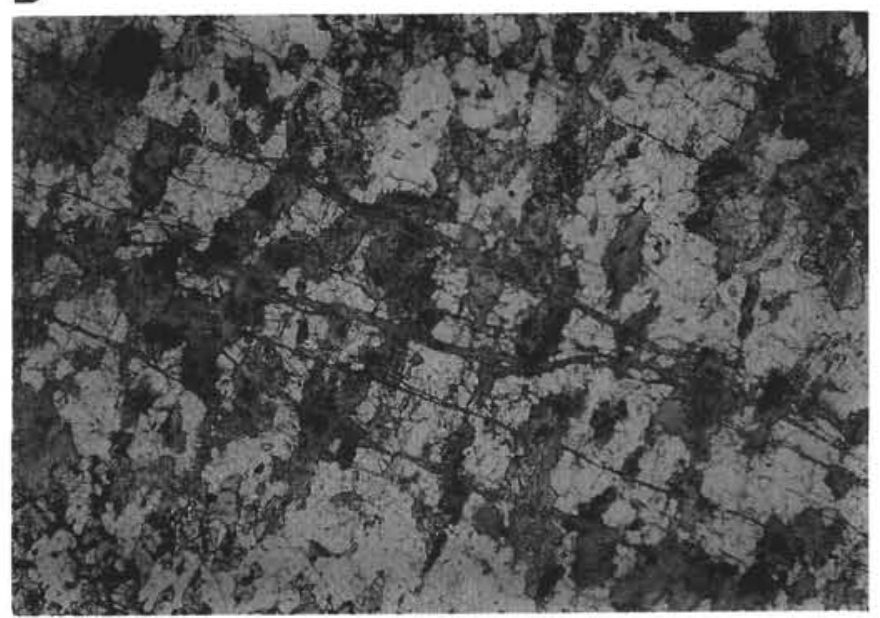

D

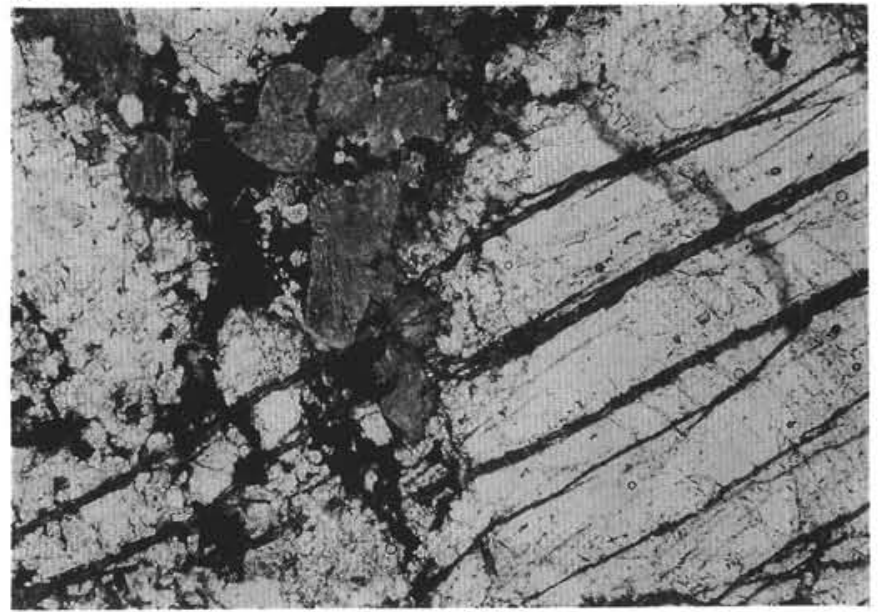

Figure 9. Photomicrographs of crosscutting relations between amphibole veins and crystal-plastic fabric elements in deformed gabbros. A. Anastomosing subparallel branches of a hornblende vein network crosscutting the foliation in a deformed olivine gabbro (Sample 153-923A-2R-2, 33-36 cm). B. Branching network of actinolite veins crosscutting the foliation and compositional banding in an amphibolite (Sample 153-923A-2R-2, 66-74 cm). C. Actinolite veins obliquely crosscutting a discrete shear zone in coarse-grained olivine gabbro. Strong fabric within the shear zone is defined by stringers of oxides (Sample 153$923 \mathrm{~A}-16 \mathrm{R}-2,41-46 \mathrm{~cm}$ ). D. Subparallel actinolitic hornblende veins cutting across a shear zone with oxide minerals in a deformed troctolite (Sample 153-922$2 \mathrm{R}-2,68-71 \mathrm{~cm}$ ). Field of view is $7 \mathrm{~mm}$, and the stratigraphic top is to the left in all photographs.

composite veins are made mainly of either smectite adjacent to plagioclase in the wallrock or radiating prehnite bundles and chlorite fibers adjacent to altered olivine and talc in the host rock. Fibrous smectite in these veins is wall-perpendicular, suggesting a pure extensional origin of the vein cracks. Where chlorite and smectite are the predominant vein-filling minerals, chlorite commonly occupies the center of the veins, whereas smectite occurs along the vein walls (e.g., Sample 153-924C-7R-1, 124-132 cm).

\section{DENSITY DISTRIBUTION AND ORIENTATION OF VEIN ASSEMBLAGES}

There is no significant difference in the occurrence of vein assemblages among Sites 921-924, although some vein generations are more common than others in cores from certain holes, and alteration intensities associated with veins and vein systems are broadly similar. Vein density was estimated by the number of vein occurrences in per meter of the core from all four sites and in each thin section examined for petrographic and microprobe analyses. However, poor core recovery in most of the drill holes prevents a meaningful deter- mination of the vein density. The vein density based on the estimates of thin-section observations is given on Table 1 for representative samples, and includes both macroscopic and microscopic veins. Density distribution of the amphibole and amphibole-chlorite-bearing veins may correlate with the occurrence and distribution of crystalplastic fabric elements (porphyroclastic texture, foliation/lineation), discrete shear zones, and cataclastically deformed zones, as the core observations and thin-section studies suggest. However, a systematic study of this correlation and its downhole variations is not feasible because of poor core recovery in the holes. The distribution of felsic veins and late-stage composite veins does not appear to be spatially and temporally associated with any of the deformation fabrics in cores. The widespread occurrence ( 10 to 15 per meter) of actinolitechlorite and chlorite veins in the uppermost sections of Hole 921B (Samples 153-921B-1W-1, Pieces 3, 4, 5, 7, and 12) corresponds to several cataclastic zones. The vein density locally increases or decreases with a corresponding increase or decrease, respectively, in crystal-plastic fabric intensity in cores from Holes 921E, 922B, 923A, and 924C. For example, a distinctive trend from high to low vein density between 60 and 65 meters below seafloor (mbsf) in Hole $921 \mathrm{E}$ coincides with an apparent decrease in the crystal-plastic fabric 


\section{A}

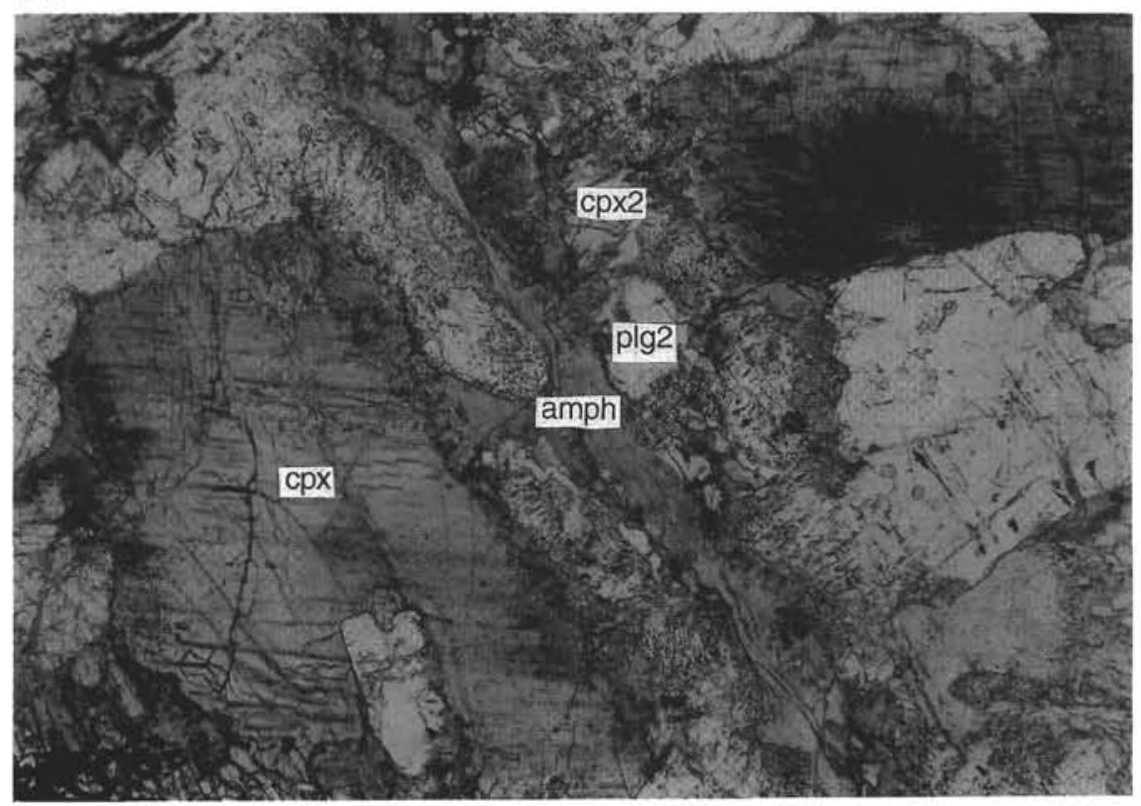

\section{B}

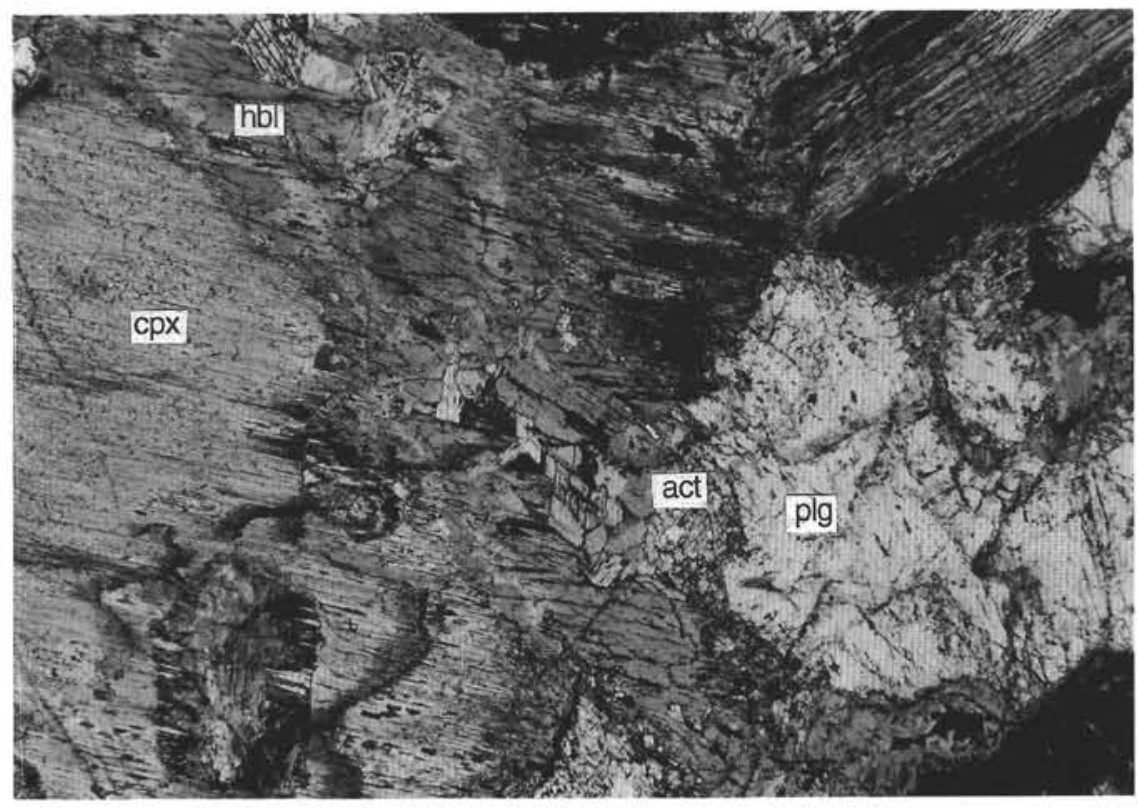

Figure 10. A. Amphibole vein with a halo containing secondary plagioclase and secondary clinopyroxene (Sample 153-921B-4R-1, 80-84 cm). B. Vein, containing green and brown hornblende, in olivine gabbro. Brown amphibole showing syntaxial overgrowth on clinopyroxene in the wallrock (Sample 153-921B-4R-1, 129-135 cm). Abbreviations are defined as follows: act $=$ actinolite, amph $=$ amphibole, $\mathrm{cpx}=$ primary clinopyroxene, $\mathrm{cpx} 2=$ secondary clinopyroxene, $\mathrm{hbl}=$ hornblende, $\mathrm{plg}=$ primary plagioclase, $\mathrm{plg} 2=$ secondary plagioclase. Field of view is 7 $\mathrm{mm}$, and the stratigraphic top is to the left in both photographs.

intensity (Fig. 16). In some cases, the average density of hydrothermal vein assemblages decreases as the dip angle of the crystal-plastic foliation shallows, as observed in cores from the intervals between 22 and $27 \mathrm{mbsf}$ and between 32 and $39 \mathrm{mbsf}$ in Hole 923A (Fig. 17). These observations indicate that the occurrence of amphibole and amphibole-chlorite veins, in general, is positively correlated with deformation intensity and with the geometry of deformation fabric. The lithology of the gabbroic rock does not seem to affect or control the distribution of hydrothermal veins at Sites 921-924.

The orientation of the amphibole, amphibole-chlorite, and chlorite veins does not show any systematic pattern in holes at Sites 921-
924. In certain depth intervals, they become steep to vertical (e.g., between 20 and 30 mbsf in Hole 921D); in general, there is a bimodal distribution to their dip angles clustering around $30^{\circ}$ and $75^{\circ}-80^{\circ}$. This is consistent with the occurrence of conjugate vein systems intersecting at oblique to high angles in many of the core samples. Paleomagnetically corrected (using the declination of stable remanence) vein attitudes from Hole 923A show that the hydrothermal veins at this site cluster with an overall shallow dip to the east (Fig. 18), similar to the hydrothermal veins in serpentinized peridotites at Site 920 further to the south (Dilek et al., this volume; Hurst et al., this volume). 
A

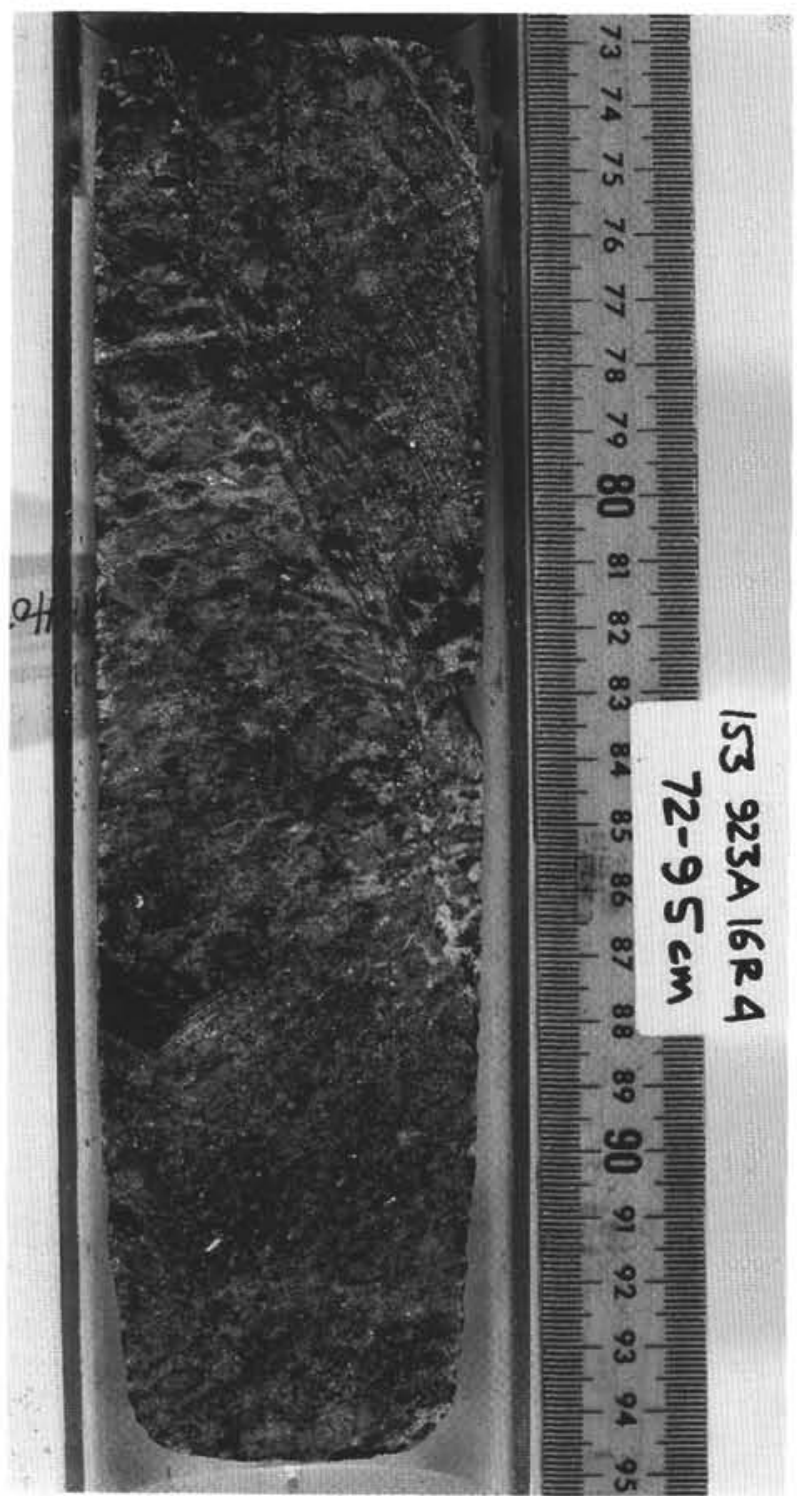

B

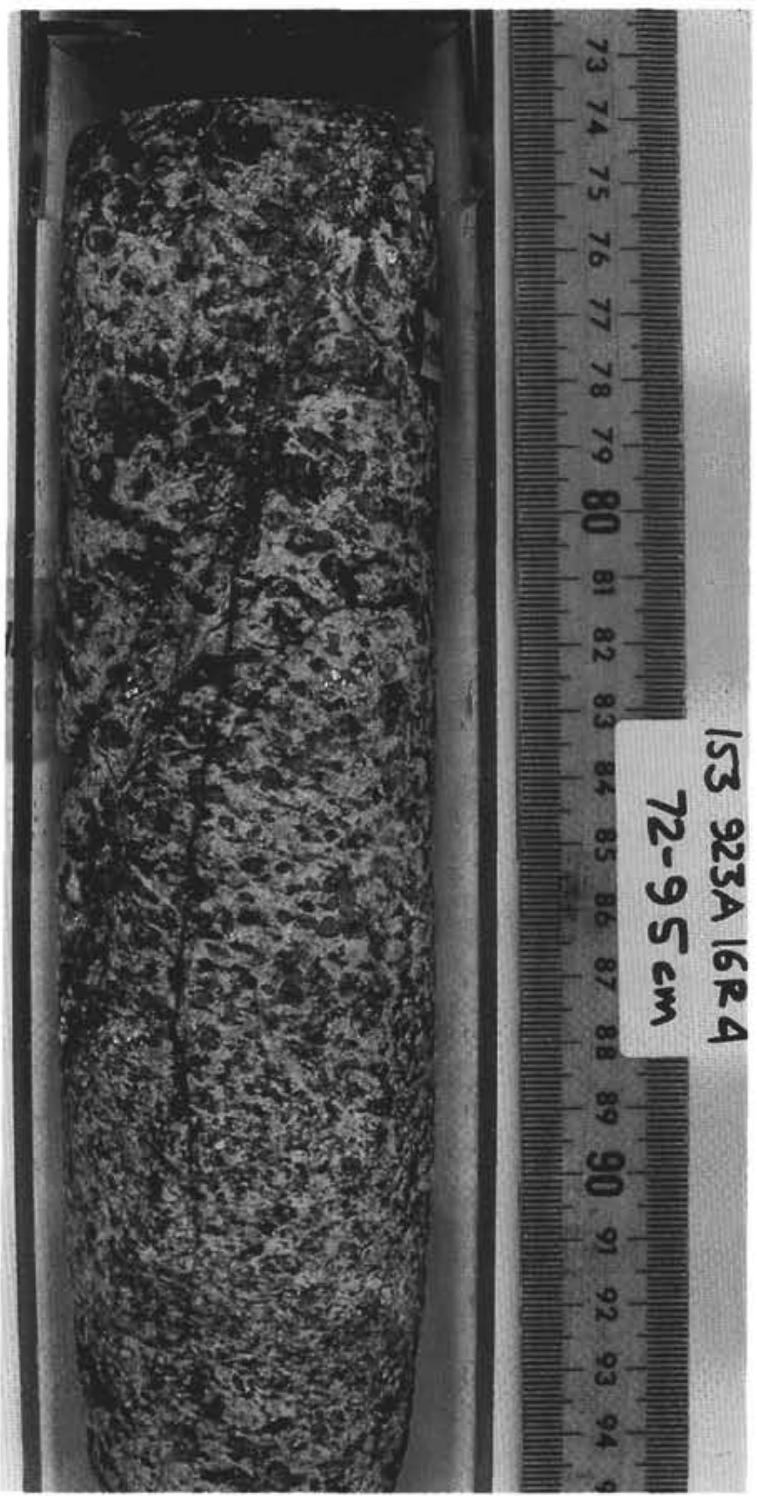

Figure 11. Actinolite-chlorite veins crosscutting crystal-plastic fabric in gneissic olivine gabbro. A and $\mathbf{B}$ show the cut face and the back surface of the archive half of Sample 153-923A-16R-4, 72-95 cm.

Late-stage composite veins commonly occur at shallow depths in the drilled holes, and they do not show any systematic trend in their distribution and orientation. They generally have steep dips (in the core reference frame) and irregular walls. Some veins containing clay minerals and zeolites are fractured possibly caused by stress release during and after coring.

\section{MINERAL CHEMISTRY AND TEMPERATURES OF ALTERATION}

A total of 45 samples was examined petrographically to study the type, geometry, internal fabric, and crosscutting relationships of different veins and vein systems in the gabbroic rocks from Sites 921 to 924. The composition of vein-filling minerals of some representative amphibole, amphibole-chlorite, and chlorite veins as well as secondary plagioclase and clinopyroxene grains along the vein walls in 20 of these samples was analyzed by computer-controlled electron mi- croprobes at the University of Leicester and University of Bristol (both JEOL JXA-8600S) in the United Kingdom and Duke University (CAMECA Camebax) in the U.S.A. A summary of the types, mineral assemblages, textures, and abundance (in thin section) of analyzed veins and groundmass assemblages is listed on Table 1. Representative amphibole and chlorite analyses are presented on Tables 2 and 3.

The majority of the vein-filling amphiboles in samples analyzed are actinolite and actinolitic hornblende (Leake, 1978). However, the amphibole compositions range from actinolite, actinolitic hornblende to iron tremolite, $\mathrm{Mg}$ hornblende, $\mathrm{Ti}$ hastingsitic hornblende, and edenitic hornblende (Tables 1,2 ). Veins with different amphibole compositions and/or single veins with changing amphibole compositions occur in the same samples. In Sample 153-921B-4R-1, 80-84 $\mathrm{cm}$, a single amphibole vein consists predominantly of amphibole, and also contains $\mathrm{Na}$ plagioclase $\left(\mathrm{An}_{14}-\mathrm{An}_{17}\right)$ and secondary pyroxene (Fig. 19). The amphibole displays varying compositions encompassing actinolite and $\mathrm{Mg}$ hornblende, but it is mostly actinolitic (Fig. 
A

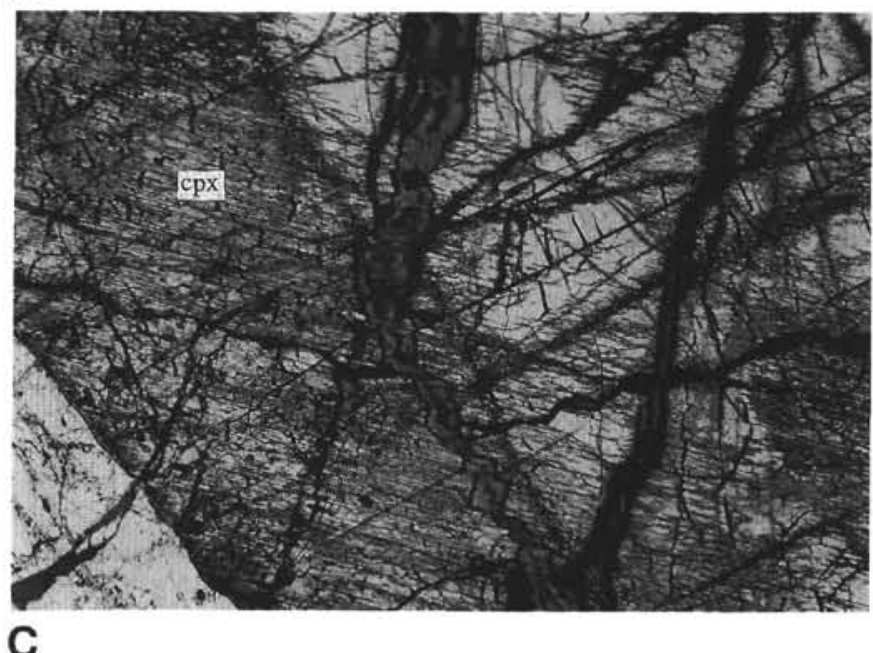

C

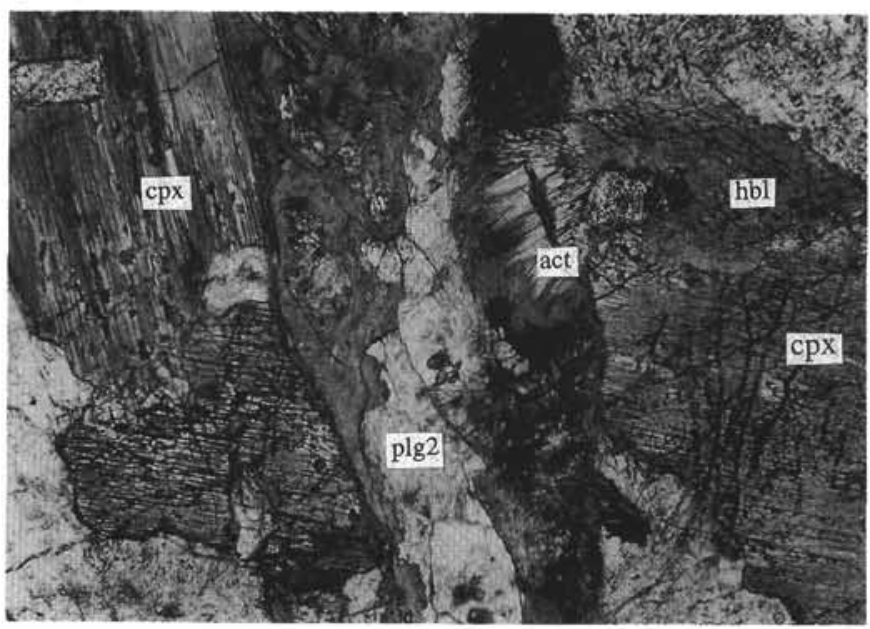

B

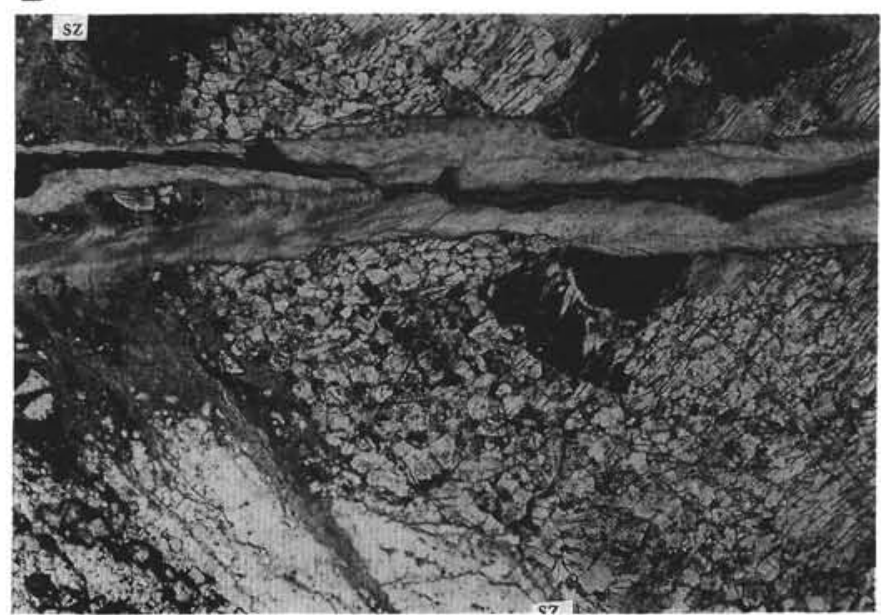

D

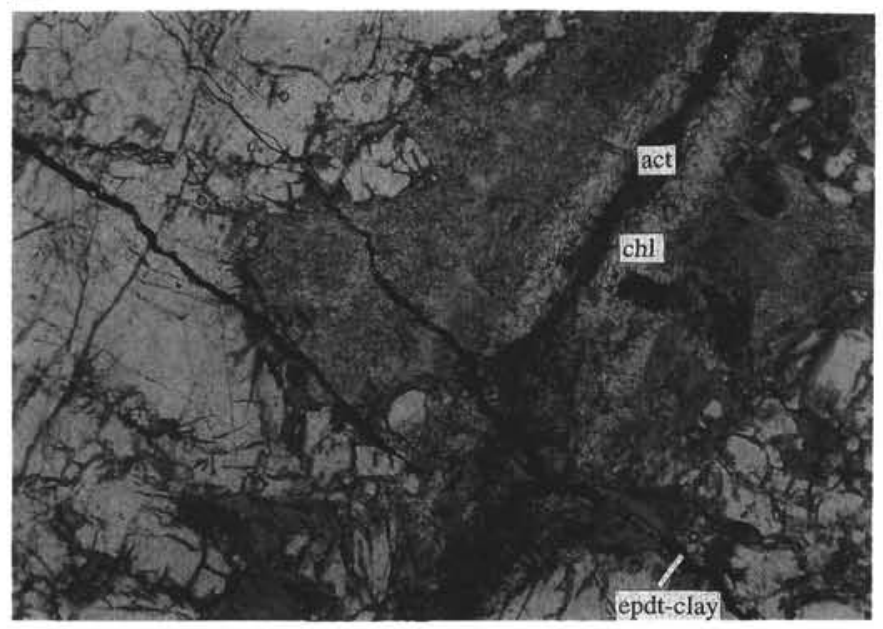

Figure 12. Various occurrences of amphibole-chlorite veins in gabbroic rocks. A. Hornblende-actinolite- and chlorite-bearing, submillimetric, en echelon veins crosscutting clinopyroxene grains in coarse-grained gabbro (Sample 153-923A-16R-4, 38-44 cm). B. Actinolite-chlorite vein crosscutting at an oblique angle a discrete shear zone (sz) in coarse-grained olivine gabbro (Sample 153-923A-16R-2, 41-46 cm). C. A hornblende-actinolite- and chlorite-bearing vein in a submillimetric shear zone (Sample 153-923A-16R-4, 38-44 cm). The vein also contains secondary plagioclase. Notice the syntaxial overgrowth of actinolite along the vein inner wall adjacent to hornblende replacing the clinopyroxene in the host rock. D. Actinolite-chlorite vein crosscutting coarse-grained olivine gabbro (Sample 153-924C-7R-1, 46-52 cm). The vein (dipping to the left) is occupied by actinolite in the core and chlorite along the walls. It is cut by en echelon segments of composite veins containing epidote + clay minerals. Abbreviations are defined as follows: act $=$ actinolite, $\mathrm{chl}=\mathrm{chlorite}, \mathrm{cpx}=\mathrm{clinopyroxene}$, epdtclay $=$ epidote + clay minerals, $\mathrm{hbl}=$ hornblende, $\mathrm{plg} 2=$ secondary plagioclase. See text for discussion of the textures. Field of view is $7 \mathrm{~mm}$, and the stratigraphic top is to the left in all photographs.

20). The vein is slightly sheared along the walls, and the elongate amphibole crystals occur at a low angle to the vein walls. Some amphibole with more aluminous compositions occur as replacement after pyroxene. Primary pyroxenes in the wallrock are more $\mathrm{Al}$ and $\mathrm{Cr}$ rich than secondary pyroxenes in the vein. In Sample 153-921B-4R-1, 129-135 cm, a 1-mm-thick vein contains mainly amphibole and some zircon. The amphibole along the vein walls is brown, whereas it is blue-green in the vein center; similarly, the amphibole composition changes from hornblende to actinolite from vein walls toward the vein center, showing zoning (Fig. 20). The plagioclase in the host rock adjacent to this vein is $\mathrm{An}_{19}$, whereas the primary plagioclase in the host rock away from the vein is $\mathrm{An}_{50}$. The amphibole replacing clinopyroxene in the groundmass away from the vein is considerably more $\mathrm{Al}$ and $\mathrm{Na}$ rich, with a lower $\mathrm{Mg}$ number than the amphibole in the vein. The change in amphibole composition may reflect the involvement of surrounding primary silicates in alteration and the level of their hydration. Analyses of secondary clinopyroxene crystals along the vein walls in both samples show significant differences in both silica content and $\mathrm{Mg}$ numbers, consistent with this interpreta- tion. Similarly, the silica content of the secondary plagioclase crystals from the vein wallrock varies considerably, ranging from 50.8 wt $\%$ to $64.6 \mathrm{wt} \%$.

Amphibole veins that are spatially associated with discrete shear zones also exhibit varying amphibole compositions. In Sample 153922A-2R-5, 39-45 cm, a 1-mm-thick, oxide-rich shear zone contains submillimetric arrays of amphibole veinlets parallel to the shear zone margins. The amphibole in these veinlets is locally zoned, and contains a colorless and relatively magnesian $\left(\mathrm{Mg} \# 74-84 ; 56.85 \% \mathrm{SiO}_{2}\right.$ content) center and blue-green rims, which are more Fe rich (Mg\# 54-60) and significantly more $\mathrm{Na}$ and $\mathrm{Al}$ rich, resulting in lower $\mathrm{SiO}_{2}$ content ( $43.39 \%$ ) compared to the center (Fig. 20). Oxides within the shear zone are slightly more $\mathrm{Fe}$ and $\mathrm{Mn}$ rich than those outside of the shear zone. Primary plagioclase in the host rock is $\mathrm{An}_{75}$, whereas plagioclase neoblasts are $\mathrm{An}_{56}-\mathrm{An}_{71}$ within the shear zone.

Amphibole-chlorite veins commonly have relatively homogeneous chlorite and varying amphibole compositions (Table 1). Sample $153-924 B-5 R-1,34-40 \mathrm{~cm}$, contains two nearly perpendicular sets of amphibole-chlorite veins; one set is cut and slightly offset by 


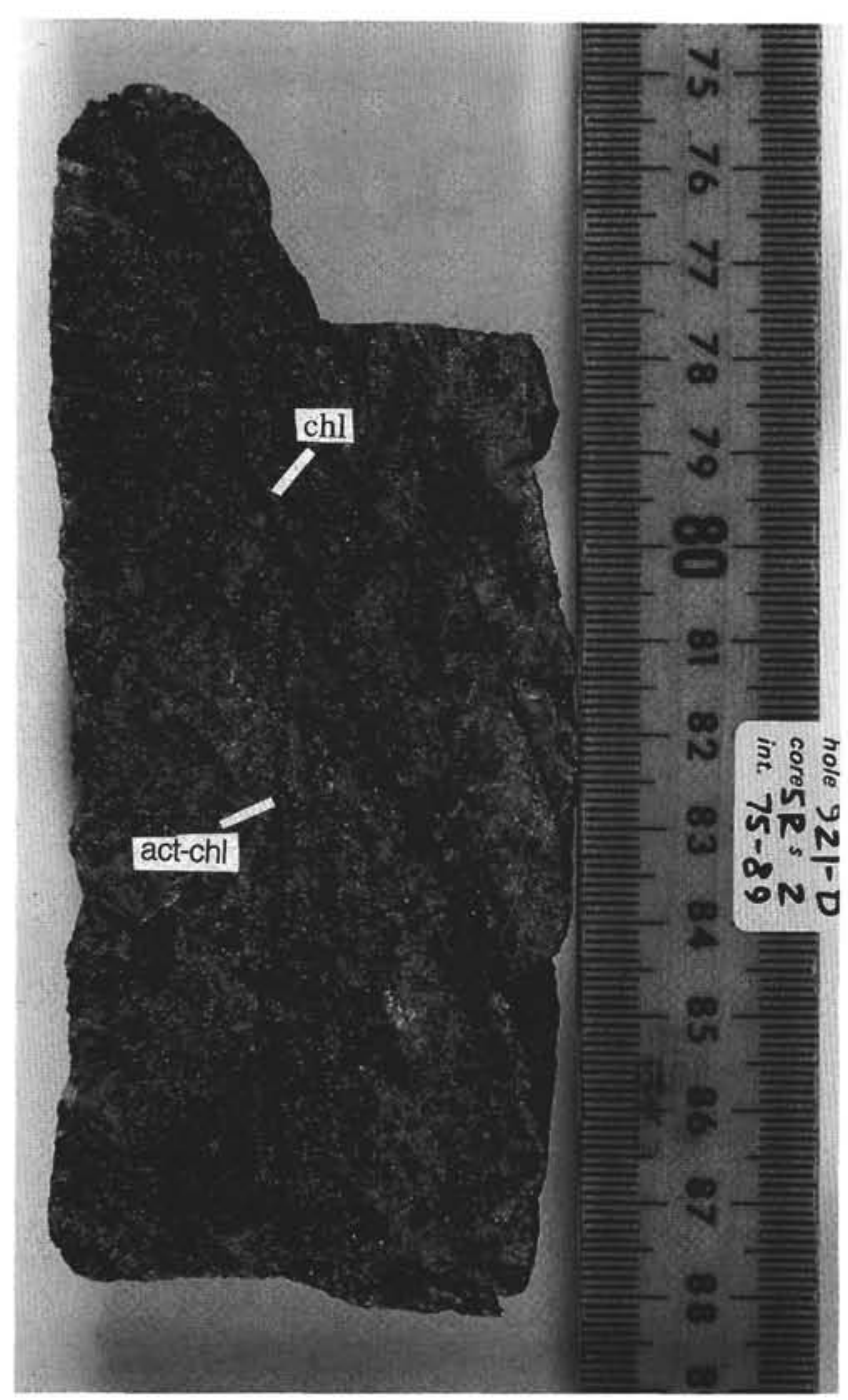

Figure 13. Chlorite (chl) vein with a yellow alteration halo dipping to the right on the core face and truncating steeply dipping actinolite-chlorite (actchl) veins. Sample 153-921D-5R-2, 78-89 cm.

the second set. The older vein set is composed mainly of fine-grained amphibole and chlorite. The chlorite displays a fibrous texture with fibers oriented perpendicular to the vein walls, and has relatively constant $\mathrm{Mg}$ numbers around 0.77 . Amphiboles in these veins are intermediate between tremolite and actinolite. Veins in the crosscutting set contain amphibole in the core and chlorite along the vein walls. Chlorite fibers are generally perpendicular to the vein walls, whereas the amphibole in the core is elongate parallel to the vein walls. The chlorite in this vein set has $\mathrm{Mg}$ numbers of $0.77-0.78$, with varying $\mathrm{SiO}_{2}$ and $\mathrm{Al}_{2} \mathrm{O}_{3}$ contents. These variations in $\mathrm{SiO}_{2}$ and $\mathrm{Al}_{2} \mathrm{O}_{3}$ are not systematic, however, with respect to the texture and/or the occurrence of the chlorite in the veins. The amphiboles are locally zoned and have tremolitic to actinolitic compositions. In Sample 153-924C7R-1, 46-52 cm, nearly 20 submillimetric amphibole-chlorite veins form two generations with no apparent offset. Chlorite commonly occurs as wall-perpendicular fibers along the vein walls, whereas amphibole as aggregates and needle-shaped fibers in the vein center (Fig.12D). The chlorites are relatively homogeneous in composition, and have the highest $\mathrm{Mg}$ numbers ( 8.2) of chlorites analyzed in this study. In contrast to the other samples, most of the amphiboles in these veins are $\mathrm{Al}$ rich, up to $14 \%$, representing more hornblendic compositions (edenitic hornblende, $\mathrm{Mg}$ hastingsite, and hastingsitic hornblende; Fig. 20); however, actinolitic amphiboles occur together with hornblendic ones in the same veins, showing complex zoning patterns.

Chlorite compositions and internal fabric in monomineralic chlorite veins are variable (Fig. 21). A single chlorite vein in Sample 153924B-5R-1, 34-40 cm, has a wall-parallel banded fabric in the core and a fibrous texture with wall-perpendicular chlorite fibers along the inner walls (Fig. 14C). The banded chlorite in the core has a slightly more $\mathrm{SiO}_{2}$-rich composition than the fibrous chlorite along the vein walls (Fig. 21), and the $\mathrm{Mg}$ numbers range from 0.76 to 0.80 . Similarly, Sample $153-924 \mathrm{C}-7 \mathrm{R}-1,46-52 \mathrm{~cm}$, contains eight to 10 submillimetric and subparallel chlorite veins that have perpendicular fibers along the vein walls and massive chlorite in the center. Although the chlorite in these veins have a mean $\mathrm{Mg}$ number of 0.82 (Fig. 21), their silica content varies from $29 \mathrm{wt} \%$ (along the walls) to $32 \mathrm{wt} \%$ (in the center). Sample 153-921D-2R-1, 94-99 cm, contains nearly 10 subparallel, 10 - to $20-\mu \mathrm{m}$-thick chlorite veins that display wallperpendicular fibers. The veins are mostly monomineralic, although one of them also contains quartz. A trace of carbonate is also found in one of the chlorite veins. The chlorite in these veins have a relatively homogeneous composition, with a $\mathrm{Mg}$ number around $0.66-$ 0.67 (Fig. 21), lower than those of the Hole 924B chlorites, and an average $\mathrm{SiO}_{2}$ content around $32 \mathrm{wt} \%$. The chlorites in this sample are the most Fe rich (some with Mg numbers around 40) among the chlorite veins analyzed in this study. A thin amphibole veinlet in the same sample also has an unusually $\mathrm{Fe}$-rich composition for its $\mathrm{SiO}_{2}$ content, consistent with the lower $\mathrm{Mg}$ numbers for the chlorites in this sample. The chlorites within a fibrous chlorite vein in Sample 153921D-2R-1, 94-99 cm, have homogeneous compositions, with a $\mathrm{Mg}$ number around 0.67 , lower than those of the Hole 924B chlorites, and an average $\mathrm{SiO}_{2}$ content around $32 \mathrm{wt} \%$ (Fig. 21).

The observed changes in amphibole and chlorite compositions in the vein assemblages are probably related to the textures and bulkrock compositions of the host rock, water/rock ratios, and temperatures and compositions of circulating fluids. Figure 22 summarizes the compositional variations of some representative primary and secondary clinopyroxenes and some representative chlorite and amphibole in veins from Sites 921 to 924. Amphiboles from Samples 153921B-4R-1, 80-84 cm, and 924B-5R-1, 34-40 cm, are predominantly low in $\mathrm{Al}$ and in $\mathrm{Na}_{2} \mathrm{O}$ (high $\mathrm{SiO}_{2}$ ) representing actinolitic compositions, whereas those from Samples 153-924C-7R-1, 46-52 cm, and $923 \mathrm{~A}-8 \mathrm{R}-2-1,76-82 \mathrm{~cm}$, have higher $\mathrm{Al}$ and variable, but tending to higher, $\mathrm{Na}_{2} \mathrm{O}$ (as a result of lower $\mathrm{SiO}_{2}$ ), producing more hornblendic compositions. In most samples, there is a roughly linear trend between $\mathrm{SiO}_{2}$ and $\mathrm{Mg}$ number, although the slope of this trend is different from sample to sample. The host rock for veins with actinolitic amphiboles is medium-grained olivine gabbro, whereas it is composed of coarse-grained gabbro (Sample 923A-8R-2, 76-82 cm) and coarse-grained meta-olivine gabbro (Sample 924C-7R-1, 46-52 cm) for veins with hornblendic compositions (Fig. 22A). Vein chlorites in deformed and metamorphosed, coarse-grained olivine gabbros from Holes $924 \mathrm{~B}$ and $924 \mathrm{C}$, respectively, have higher $\mathrm{Mg}$ numbers than those in a medium-grained and undeformed gabbro from Hole 921D (Fig. 22A), in which the chlorite are very Fe rich. This may point to low water/rock ratios in Hole $921 \mathrm{D}$ gabbros that resulted in a rapid change in fluid composition, producing highly evolved, Fe-rich fluids, from which the chlorite veins were precipitated. The clinopyroxenes analyzed in this study fall into three groups: primary, altered primary, and secondary vein clinopyroxenes (Table 4; Fig. 22B). Secondary vein clinopyroxenes occur abundantly in Sample 153921B-4R-1, 80-84 cm, and are present in Sample 153-924C-7R-1, $46-52 \mathrm{~cm}$. The secondary vein clinopyroxenes in Sample 153-921B$4 \mathrm{R}-1,80-84 \mathrm{~cm}$, have high $\mathrm{SiO}_{2}$ (low $\mathrm{Al}_{2} \mathrm{O}_{3}$ ), high $\mathrm{Ca}$, and lower $\mathrm{Mg}$ numbers than the primary clinopyroxenes from this sample. In general, the secondary clinopyroxenes in those samples, which have primary clinopyroxenes with low $\mathrm{Mg}$ number, tend to have low $\mathrm{Mg}$ numbers, suggesting that the composition of the gabbroic rocks might have affected the composition of the secondary phases. This 
A

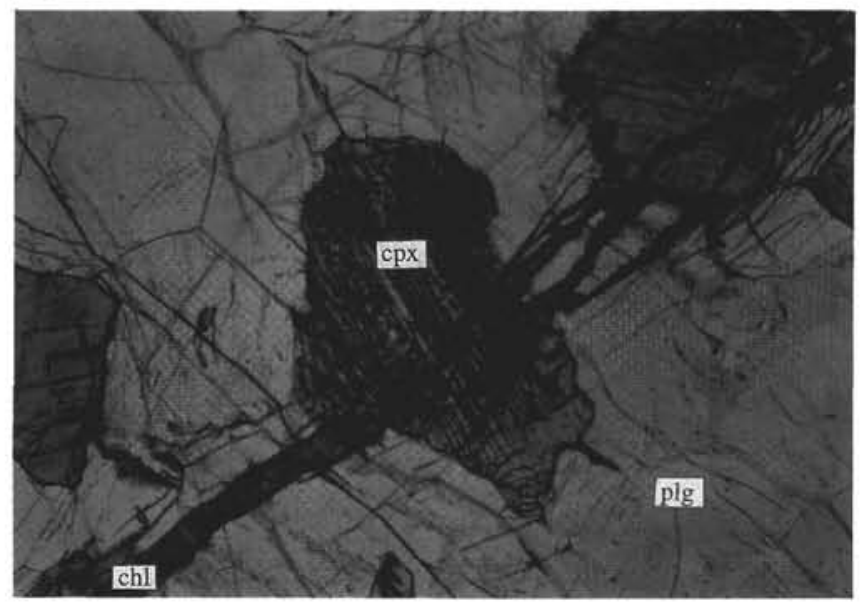

C

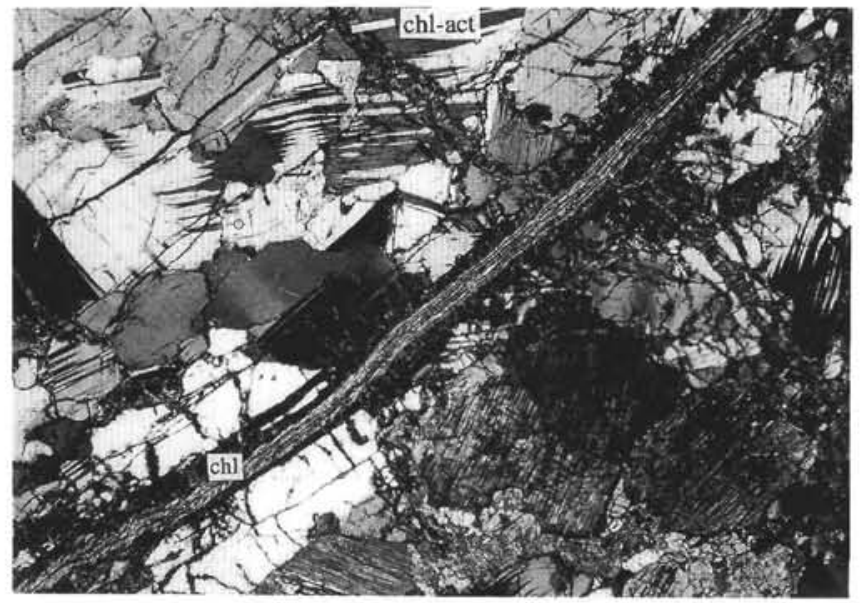

B

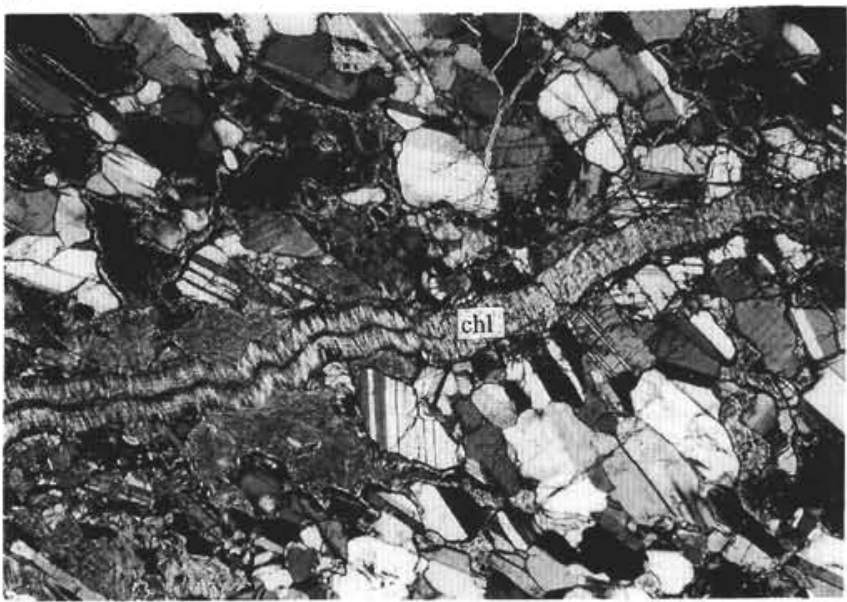

D

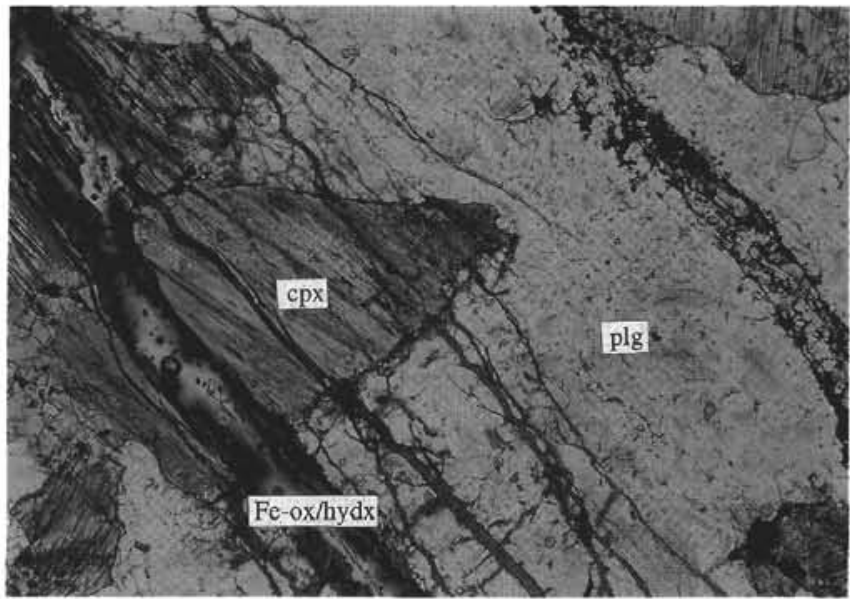

Figure 14. Various chlorite vein occurrences with different internal fabrics in gabbroic rocks. A. Submillimetric chlorite veinlets crosscut plagioclase and clinopyroxene grains in coarse-grained gabbro (Sample 153-921D-5R-1, 73-81 cm). B. Wall-perpendicular chlorite fibers in a monomineralic chlorite vein in coarse-grained troctolite (Sample 153-924C-6R-1, 31-39 cm). C. Submillimetric chlorite vein (dipping to the left) crosscuts and offsets an actinolite-chlorite vein in medium-grained olivine gabbro (Sample 153-924B-5R-1, 34-40 cm). The chlorite vein contains wall-parallel bands in the core and wall-perpendicular fibers along the inner walls. Stringers of the adjacent host rock occur within the chlorite vein. D. Iron oxide/hydroxide replacing a chlorite vein in deformed olivine gabbro (Sample 153-923A-16R-4, 79-85 cm). Abbreviations are defined as follows: $\mathrm{chl}=$ chlorite, $\mathrm{cpx}=$ clinopyroxene, Fe ox/hydx $=$ iron oxide/hydroxide, $\mathrm{plg}=$ plagioclase, $\mathrm{chl}$-act $=$ chlorite + actinolite. See text for discussion of the textures. Field of view is $7 \mathrm{~mm}$, and the stratigraphic top is to the left in all photographs.

relation between the host rock composition and vein mineralogy holds true particularly when the water/rock ratios are low in the hydrothermal system (Mottl, 1983; Gillis et al., 1993). Zoning of amphibole from more hornblendic along the vein walls to more actinolitic in the vein cores in some vein systems may also indicate progressively lower temperatures of the fluids percolating through the previously filled cracks.

The widespread occurrence of actinolite in the hydrothermal veins and in the groundmass of the gabbroic rocks from Sites 921 to 924 suggests fluid temperatures around $300^{\circ} \mathrm{C}$ during brittle deformation accompanied by vein development (Liou et al., 1974; Spear, 1980). The existence of actinolitic hornblende, $\mathrm{Mg}$ hornblende, and edenitic hornblende in the monomineralic amphibole veins most likely indicates even higher temperatures (Robinson et al., 1982). Limited occurrence of equilibrium mineral assemblages in hydrothermal veins, combined with poor core recovery and shallow penetration in the holes, makes it difficult to obtain a wide database to estimate accurate temperatures of alteration. Compositional zoning patterns in vein amphiboles point to sequential crystallization, and may be a result of either a progressive change in external conditions or the evolved nature of the reacting fluid phase composition. The results of geothermometric calculations based on the compositions of hornblende and secondary plagioclase in equilibrium from Sample 153$921 \mathrm{~B}-4 \mathrm{R}-1,80-84 \mathrm{~cm}$, indicate temperatures up to $380^{\circ} \mathrm{C}$ based on Blundy and Holland's (1990) empirical calibration. These temperatures are consistent with upper greenschist/amphibolite transitional facies metamorphic conditions during hydrothermal veining in the gabbroic rocks. Chlorite compositions of the analyzed samples indicate temperatures of chlorite equilibration of $150^{\circ}-200^{\circ} \mathrm{C}$ based on the empirical chlorite solid solution geothermometer of Cathelineau and Nieva (1985). These findings indicate the generation of lowertemperature alteration minerals and veins, and retrograde development of greenschist-type assemblages with progressive cooling of the gabbroic rocks in the MARK area.

\section{TECTONIC IMPLICATIONS AND DISCUSSION}

Locally strongly developed porphyroclastic to gneissic textures, foliation/lineation, and discrete shear zones reflect a high-tempera- 
A

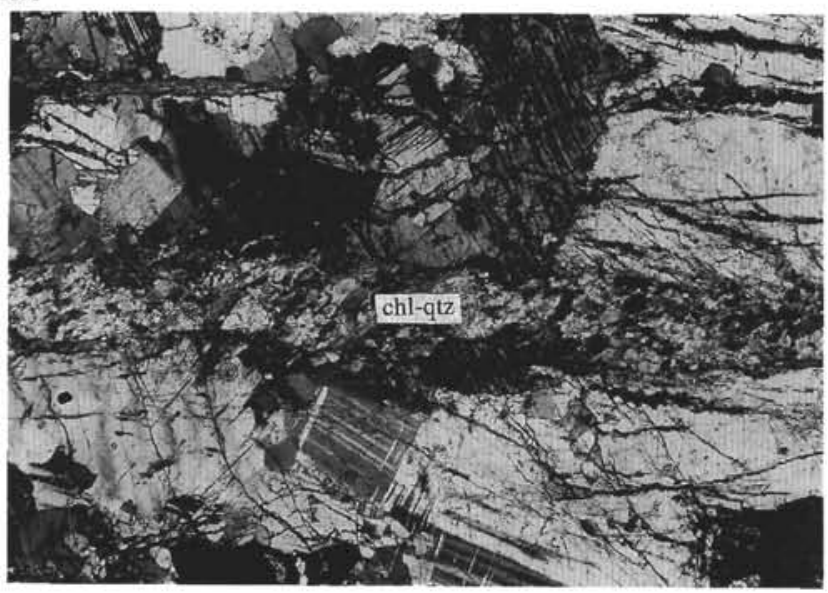

B

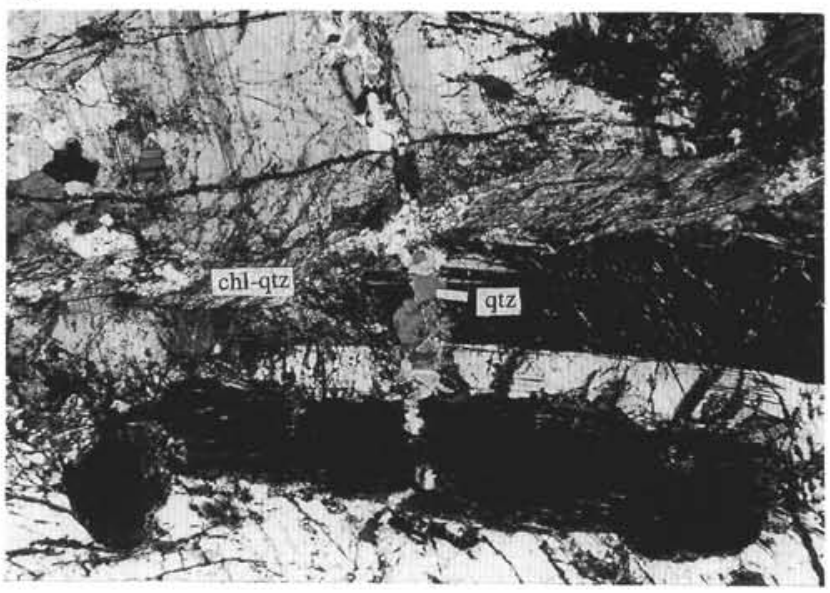

Figure 15. Chlorite-quartz (A) and quartz (B) containing composite veins. Sample 153-921D-2R-1, 94-99 cm. Abbreviations are defined as follows: chl-qtz $=$ chlorite + quartz, $q t z=$ quartz. Field of view is $7 \mathrm{~mm}$, and the stratigraphic top is to the left in both photographs.

ture crystal-plastic deformation episode that the gabbroic rocks from Sites 921 to 924 underwent during the initial stages of tectonic extension in a slow-spreading ridge environment in the MARK area. The spatial association of synkinematic amphibole and recrystallization of olivine, plagioclase, and pyroxene within these shear zones and deformation fabrics indicates that crystal-plastic deformation probably occurred at temperatures $>700^{\circ} \mathrm{C}$ (Liou et al., 1974; Spear, 1980). The occurrence of synkinematic hornblende/actinolite within the discrete shear zones suggests the infiltration of external fluid phase into the rock along these zones of weakness and high permeability as the temperatures decreased. Changes in plagioclase compositions towards albite enrichment in and across the discrete shear zones indicate that the fluid(s) percolated through channels within the shear zones were $\mathrm{Na}$ rich, possibly of seawater origin. This albitization within the shear zones suggests high water/rock ratios and moderate temperatures (Seyfried et al., 1988; Gillis et al., 1993). The extensional nature (normal sense of shearing) of most of the discrete shear zones indicates that the penetration of fluids into the gabbros was facilitated by stretching and brittle-ductile failure of the lower crust. The widespread occurrence of foliated ferrogabbro and oxides preferentially within and along some of the discrete shear zones suggests that these shear zones acted as "high permeability pathways" that controlled late magmatic (evolved) and subsolidus fluid flow in the gabbroic rocks. Similar observations have been made in gabbroic rocks from Hole 735B (Dick et al., 1991a; Magde et al., 1995). Can- nat (1991) and Cannat et al. (1991a) suggested that Fe-Ti oxides in mylonitic shear zones in Site 735 gabbros are of magmatic origin and that their preferential occurrence along and within the mylonitic shear zones was largely controlled by the magmatic stratigraphy in the lower oceanic crust. This interpretation is probably valid for the sheared Fe-Ti oxide horizons in the Site 921-924 gabbros.

Felsic veins crosscutting the deformation fabrics in the gabbroic rocks represent late magmatic injections (Cannat, Karson, Miller, et al., 1995) and indicate the existence of a differentiated magma body near the already deformed gabbros. Their injection into the gabbroic rocks might have been either contemporaneous with or slightly postdate moderate- to high-temperature hydration along the discrete shear zones because they predate the precipitation of amphibolechlorite and amphibole veins that are spatially associated with these shear zones.

The occurrence of amphibole veins along and across the discrete shear zones suggests that hydrothermal flow was facilitated by crack networks within and adjacent to these deformation fabrics. Changes in amphibole compositions from pargasitic and edenitic hornblende to actinolitic hornblende and actinolite in these veins, in conjunction with the disappearance of secondary clinopyroxene, suggest a progressive lowering of the temperatures from amphibolite facies to greenschist/amphibolite transitional facies metamorphic conditions. Compositional zoning of vein amphiboles also points to progressive cooling as well as changing water/rock ratios and water/rock reactions. Widespread amphibole-chlorite and chlorite veins overprinting and crosscutting the shear zones, high-temperature fabrics, and some amphibole veins indicate a new phase of alteration under greenschist facies metamorphic conditions, with further cooling of the gabbroic rocks. Where the actinolite-chlorite vein systems overprint the shear zones, synkinematic hornblende is commonly replaced by green hornblende and porphyroclasts are pervasively altered. The paleomagnetically corrected measurements of actinolite-chlorite and chlorite veins from Hole $923 \mathrm{~A}$ show a mean attitude of $\mathrm{N} 3 \mathrm{E} / 23^{\circ} \mathrm{SE}$ (Fig. 18), which is parallel to the orientations of observed low-angle faults and schistosity planes in the MARK area (Karson and Dick, 1983; Karson et al., 1987; Mével et al., 1991; Cannat et al., 1995). This suggests that the orientation and development of these greenschist vein assemblages were probably controlled by brittle deformation that produced east-dipping normal faults. Pure extensional chlorite veins and anastomosing chlorite vein systems in the footwall of several extensional faults in the core support this interpretation, and indicate the development of distributed microfractures and fracture networks in the uplifted fault blocks. Some of the subvertical to vertical, latestage chlorite veins may be related, however, to cracking fronts at temperatures below $500^{\circ} \mathrm{C}$ with further cooling of the uplifted and exhumed lower oceanic crust. Similarly, rare composite veins composed of epidote \pm plagioclase \pm quartz \pm prehnite \pm oxide \pm clay minerals may be related to cracking front and represent sealed cracks developed during unloading and emplacement of the gabbroic rocks on the seafloor.

Cataclastic zones in the uppermost sections of some of the holes (i.e., Sections 153-921B-1W-1, 921C-1W-1, and 923A-1W-1) and in certain intervals at depth (e.g., Sections 153-923A-15R-1 and 15R2) probably represent extensional fault domains where lithospheric stretching of the lower crust occurred via brittle-ductile deformation (Karson and Dick, 1983; Mével et al., 1991). These cataclastic rocks contain gabbroic clasts that have fractures filled with brown hornblende, extensive veins and vein networks of chlorite \pm epidote \pm clay minerals \pm prehnite, and/or fractured plagioclase and pyroxene grains set in a matrix of fine-grained fault gauge (e.g., Sample 153-923A$1 \mathrm{~W}-1$, Piece 1). These features indicate that previously deformed and altered gabbroic rocks underwent cataclastic deformation and associated hydrothermal alteration to greenschist assemblages in some latestage fault zones. Evidence for late-stage faulting also includes the existence in the core of faults truncating and offsetting some actinolite-chlorite and chlorite veins. These faults were probably related to 
Figure 16. Downhole variation in fabric intensity, vein dip angles, and vein density in Hole 921E. Amphibole, amphibole-chlorite, and chlorite veins were measured. See text for discussion. Intensity of plastic fabric is based on the attenuation and degree of preferred alignment of porphyroclasts and/or on the spacing of foliation planes as observed in the working half of the core; intensity of brittle fabric is based on the frequency and spacing of joints and faults along the central divide of the working half of the core piece (for details, see Shipboard Scientific Party, 1995) . Rec. $=$ core recovery.

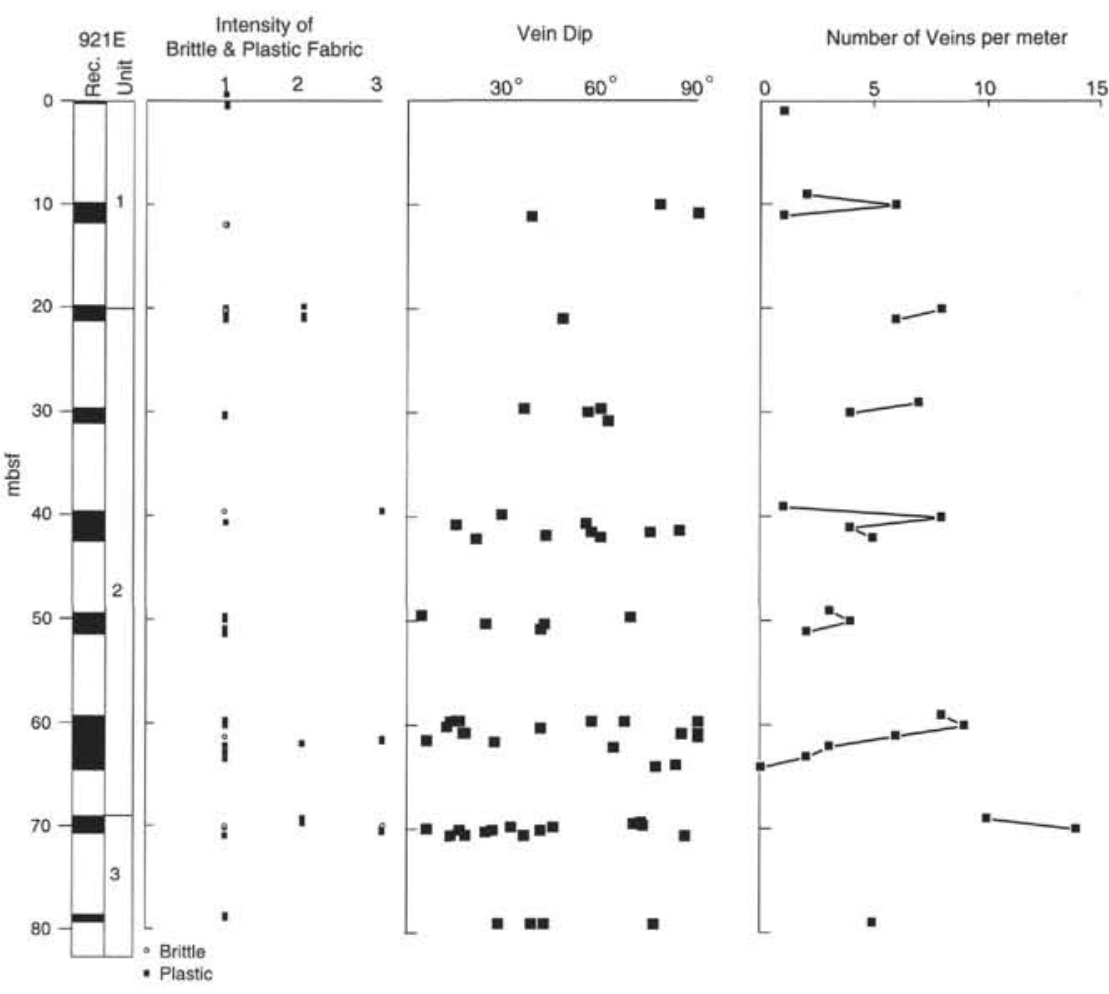

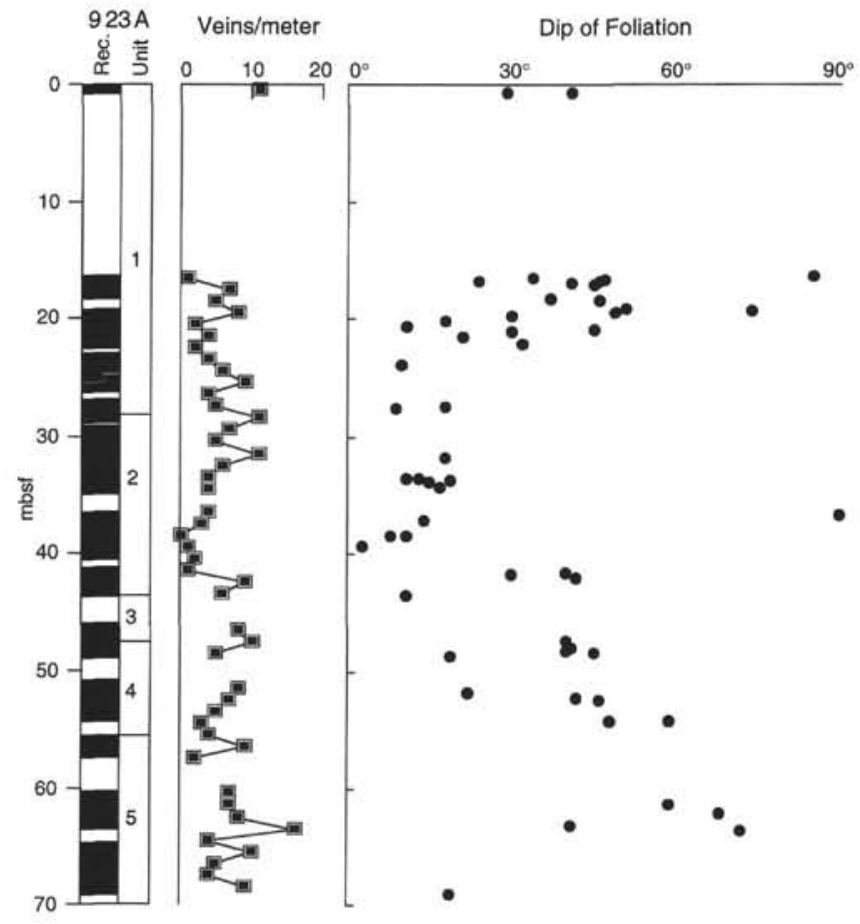

Figure 17. Downhole variation in vein density and foliation dip in Hole $923 \mathrm{~A}$. Vein density reflects the number of veins encountered per meter of core (working half). Measured veins include amphibole, amphibole-chlorite, and chlorite veins. Rec. $=$ core recovery .

the emplacement of the lower crustal blocks in the ridge-transform intersection massif on the west shoulder of the median valley.

Spatial and temporal relationships between deformation fabrics and metamorphic features in the gabbroic rocks recovered from Sites 921 to 924 attest to the integrated effects of polyphase deformational episodes and progressive strain localization, metamorphic recrystal-

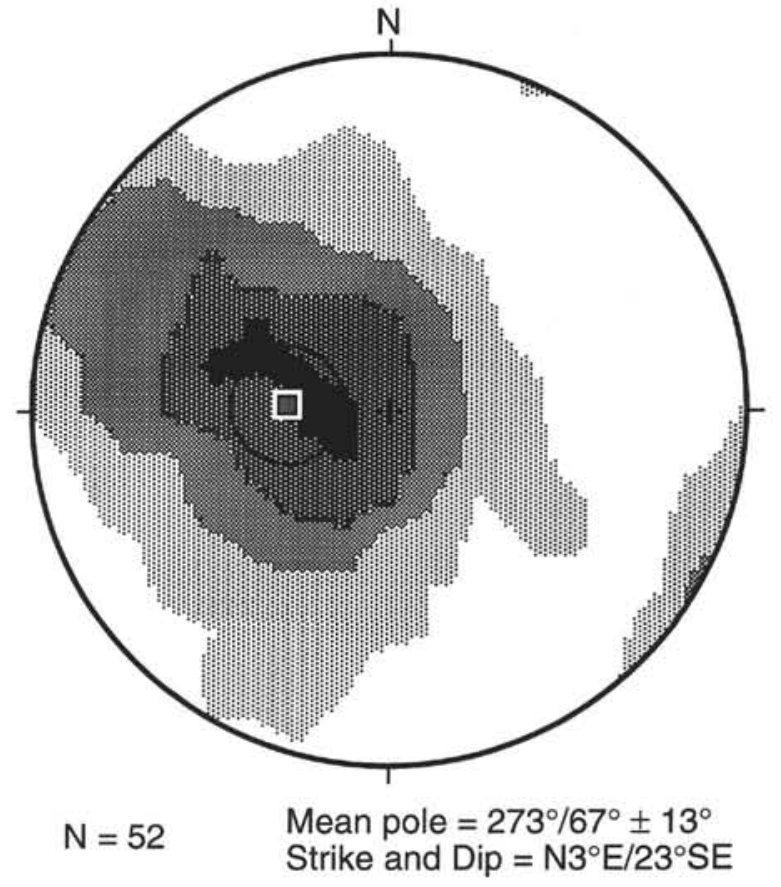

Figure 18. Equal-area Kamb contour diagram of hydrothermal (amphibole, amphibole-chlorite, and chlorite) veins in gabbroic rocks from Hole 923A. Contour interval is $2 \sigma$. See text for discussion.

lization, and alteration that occurred under conditions of decreasing temperatures and increasing hydration (Cannat, Karson, Miller, et al., 1995; Kelley, this volume; this study). This progressive cooling history of lower crustal rocks was associated with their uplifting and exhumation on the seafloor that was accompanied by brittle deformation and hydrothermal alteration.

The history of brittle deformation and attendant hydrothermal alteration in gabbroic rocks from Sites 921 to 924 in the MARK area is 
Table 2. Representative vein amphibole data from gabbroic rocks (Sites 921-924, MARK area).

\begin{tabular}{|c|c|c|c|c|c|c|}
\hline Sample: & $\begin{array}{c}153-921 \mathrm{~B}-4 \mathrm{R}-1 \\
80-84 \mathrm{~cm}\end{array}$ & $\begin{array}{c}153-921 \mathrm{~B}-4 \mathrm{R}-1 \\
80-84 \mathrm{~cm}\end{array}$ & $\begin{array}{c}153-92 \text { IB-4R-1, } \\
80-84 \mathrm{~cm}\end{array}$ & $\begin{array}{c}153-921 \mathrm{~B}-4 \mathrm{R}-1 \\
129-135 \mathrm{~cm}^{\ddagger}\end{array}$ & $\begin{array}{c}153-921 \mathrm{~B}-4 \mathrm{R}-1 \\
129-135 \mathrm{~cm}^{\ddagger}\end{array}$ & $\begin{array}{c}153-921 \mathrm{~B}-4 \mathrm{R}-1 \\
129-135 \mathrm{~cm}^{4}\end{array}$ \\
\hline \multicolumn{7}{|l|}{ Oxide (wt\%) } \\
\hline $\mathrm{SiO}_{2}$ & 54.76 & 43.16 & 57.01 & 46.44 & 53.52 & 45.53 \\
\hline $\mathrm{TiO}_{2}$ & 0.13 & 2.67 & 0.01 & 0.39 & 0.07 & 0.85 \\
\hline $\mathrm{Al}_{2} \mathrm{O}_{3}$ & 1.44 & 12.50 & 0.60 & 8.87 & 3.04 & 9.30 \\
\hline $\mathrm{Cr}_{2} \mathrm{O}_{3}$ & 0.11 & 0.38 & $<$ d.1. & 0.02 & 0.06 & 0.04 \\
\hline $\mathrm{FeO}$ (total) & 12.37 & 7.66 & 8.53 & 10.80 & 8.84 & 13.08 \\
\hline $\mathrm{MnO}$ & 0.24 & 0.05 & 0.22 & 0.19 & 0.29 & 0.26 \\
\hline $\mathrm{MgO}$ & 15.91 & 15.87 & 18.38 & 16.11 & 19.29 & 13.10 \\
\hline $\mathrm{CaO}$ & 12.42 & 12.01 & 12.16 & 11.40 & 11.56 & 12.52 \\
\hline $\mathrm{Na} 2 \mathrm{O}$ & 0.12 & 2.36 & 0.16 & 1.85 & 0.63 & 1.41 \\
\hline $\mathrm{K}_{2} \mathrm{O}$ & 0.02 & 0.26 & 0.03 & 0.20 & 0.13 & 0.15 \\
\hline Total & 97.52 & 97.92 & 97.10 & 96.27 & 97.43 & 96.24 \\
\hline \multicolumn{7}{|l|}{ Cations } \\
\hline $\mathrm{Si}$ & 7.867 & 6.270 & 8.043 & 6.682 & 7.595 & 6.783 \\
\hline $\mathrm{Al}^{\mathrm{IV}}$ & 0.133 & 1.730 & 0.000 & 1.318 & 0.405 & 1.217 \\
\hline $\mathrm{Al}^{\mathrm{VI}}$ & 0.111 & 0.410 & 0.100 & 0.218 & 0.103 & 0.416 \\
\hline $\mathrm{Ti}$ & 0.014 & 0.292 & 0.001 & 0.043 & 0.007 & 0.095 \\
\hline $\mathrm{Fe}\left(\right.$ as $\left.\mathrm{Fe}^{2+}\right)$ & 1.486 & 0.931 & 1.006 & 1.327 & 1.049 & 1.630 \\
\hline $\mathrm{Mn}$ & 0.029 & 0.006 & 0.026 & 0.024 & 0.035 & 0.033 \\
\hline $\mathrm{Mg}$ & 3.408 & 3.437 & 3.866 & 3.529 & 4.081 & 2.909 \\
\hline $\mathrm{Ca}$ & 1.912 & 1.869 & 1.838 & 1.795 & 1.758 & 1.998 \\
\hline $\mathrm{Na}$ & 0.033 & 0.665 & 0.044 & 0.527 & 0.173 & 0.407 \\
\hline K & 0.004 & 0.048 & 0.005 & 0.037 & 0.024 & 0.029 \\
\hline Mg\# * & 0.696 & 0.787 & 0.793 & 0.727 & 0.796 & 0.641 \\
\hline Name: & Actinolite & Ti hastingsite & Actinolite & Hornblende & Hornblende & Hornblende \\
\hline Description: & In vein & Replacing clinopyroxene & Adjacent to vein & In vein, core of grain & In vein, outer core & In vein, rim of grain \\
\hline Sample: & $\begin{array}{c}153-921 \mathrm{D}-2 \mathrm{R}-1 \\
94-99 \mathrm{~cm}\end{array}$ & $\begin{array}{c}153-921 \mathrm{D}-2 \mathrm{R}-1 \\
94-99 \mathrm{~cm}\end{array}$ & $\begin{array}{c}153-922 \mathrm{~A}-2 \mathrm{R}-5 \\
39-45 \mathrm{~cm}\end{array}$ & $\begin{array}{c}153-922 A-2 R-5, \\
39-45 \mathrm{~cm}\end{array}$ & $\begin{array}{c}153-923 \mathrm{~A}-8 \mathrm{R}-2 \\
76-82 \mathrm{~cm}\end{array}$ & \\
\hline \multicolumn{7}{|l|}{ Oxide (wt $\%$ ) } \\
\hline $\mathrm{SiO}_{2}$ & 49.35 & 53.38 & 56.85 & 43.39 & 46.75 & \\
\hline $\mathrm{TiO}_{2}$ & 0.32 & 0.10 & 0.00 & 0.52 & 0.47 & \\
\hline $\begin{array}{l}\mathrm{Al}_{2} \mathrm{O}_{3} \\
\mathrm{Cr}_{2} \mathrm{O}_{3}\end{array}$ & $\begin{array}{l}5.80 \\
<\text { d.I. }\end{array}$ & $\begin{array}{l}1.53 \\
<\mathrm{d} .1\end{array}$ & $\begin{array}{c}0.48 \\
<\mathrm{d} .1 .\end{array}$ & $\begin{array}{r}11.44 \\
0.03\end{array}$ & $\begin{array}{l}8.58 \\
0.04\end{array}$ & \\
\hline $\mathrm{FeO}$ & 17.49 & 14.00 & 6.85 & $\begin{array}{r}0.03 \\
16.46\end{array}$ & $\begin{array}{r}0.04 \\
12.55\end{array}$ & \\
\hline $\mathrm{MnO}$ & 0.48 & 0.38 & 0.13 & 0.29 & 0.19 & \\
\hline $\mathrm{MgO}$ & 11.82 & 15.27 & 20.34 & 10.73 & 14.60 & \\
\hline $\mathrm{CaO}$ & 10.51 & 11.45 & 13.14 & 11.87 & 12.50 & \\
\hline $\mathrm{Na}_{2} \mathrm{O}$ & 0.87 & 0.21 & 0.14 & 2.45 & 1.82 & \\
\hline $\mathrm{K}_{2} \mathrm{O}$ & 0.02 & 0.05 & 0.10 & 0.11 & 0.24 & \\
\hline Total & 96.66 & 96.37 & 98.03 & 97.29 & 97.74 & \\
\hline \multicolumn{7}{|l|}{ Cations } \\
\hline $\mathrm{Si}$ & 7.361 & 7.824 & 7.925 & 6.523 & 6.842 & \\
\hline $\mathrm{Al}^{\mathrm{IV}}$ & 0.639 & 0.176 & 0.075 & 1.477 & 1.158 & \\
\hline $\mathrm{Al}^{\mathrm{VI}}$ & 0.381 & 0.088 & 0.004 & 0.550 & 0.322 & \\
\hline $\mathrm{Ti}$ & 0.036 & 0.011 & 0.000 & 0.059 & 0.052 & \\
\hline $\mathrm{Fe}\left(\right.$ as $\left.\mathrm{Fe}^{2+}\right)$ & 2.182 & 1.716 & 0.799 & 2.069 & 1.536 & \\
\hline $\mathrm{Mn}$ & 0.061 & 0.047 & 0.015 & 0.037 & 0.024 & \\
\hline $\mathrm{Mg}$ & 2.628 & 3.337 & 4.227 & 2.405 & 3.185 & \\
\hline $\mathrm{Ca}$ & 1.680 & 1.798 & 1.963 & 1.912 & 1.960 & \\
\hline $\mathrm{Na}$ & 0.252 & 0.060 & 0.038 & 0.714 & 0.516 & \\
\hline $\mathrm{K}$ & 0.004 & 0.009 & 0.018 & 0.021 & 0.045 & \\
\hline Mg\# & 0.546 & 0.660 & 0.841 & 0.537 & 0.675 & \\
\hline Name: & Mg hornblende & Actinolite & Actinolite & Pargasitic hornblende & $\mathrm{Mg}$ hornblende & \\
\hline Description: & In vein & After clinopyroxene & Core, in shear zone & Rim, in shear zone & In vein & \\
\hline Sample: & $\begin{array}{c}153-924 \mathrm{~B}-5 \mathrm{R}-1, \\
34-40 \mathrm{~cm}\end{array}$ & $\begin{array}{c}153-924 \mathrm{C}-7 \mathrm{R}-1 \\
46-52 \mathrm{~cm}\end{array}$ & $\begin{array}{c}153-924 \mathrm{C}-7 \mathrm{R}-1 \\
46-52 \mathrm{~cm}\end{array}$ & $\begin{array}{c}153-924 C-7 R-1, \\
46-52 \mathrm{~cm}\end{array}$ & & \\
\hline \multicolumn{7}{|l|}{ Oxide (wt $\%$ ) } \\
\hline $\mathrm{SiO}_{2}$ & 54.95 & 43.24 & 54.47 & 45.53 & & \\
\hline $\mathrm{TiO}_{2}$ & 0.06 & 0.83 & 0.24 & 0.19 & & \\
\hline $\mathrm{Al}_{2} \mathrm{O}_{3}$ & 1.73 & 12.39 & 3.18 & 11.48 & & \\
\hline $\begin{array}{l}\mathrm{Cr}_{2} \mathrm{O}_{3} \\
\mathrm{FeO}\end{array}$ & $\begin{array}{l}0.01 \\
2.35\end{array}$ & $\begin{array}{r}0.18 \\
1263\end{array}$ & 0.01 & 0.02 & & \\
\hline $\begin{array}{l}\mathrm{FeO} \\
\mathrm{MnO}\end{array}$ & $\begin{array}{l}2.35 \\
0.20\end{array}$ & $\begin{array}{r}12.63 \\
0.11\end{array}$ & 5.58 & 9.42 & & \\
\hline $\begin{array}{l}\mathrm{MnO} \\
\mathrm{MgO}\end{array}$ & $\begin{array}{r}0.20 \\
23.27\end{array}$ & $\begin{array}{r}0.11 \\
13.54\end{array}$ & $\begin{array}{r}0.08 \\
20.75\end{array}$ & $\begin{array}{r}0.04 \\
15.79\end{array}$ & & \\
\hline $\mathrm{CaO}$ & $\begin{array}{l}23.27 \\
13.85\end{array}$ & $\begin{array}{l}13.54 \\
11.95\end{array}$ & $\begin{array}{l}20.75 \\
12.19\end{array}$ & $\begin{array}{l}15.79 \\
12.15\end{array}$ & & \\
\hline $\mathrm{Na}_{2} \mathrm{O}$ & $<$ d.1. & 2.99 & 0.94 & 2.85 & & \\
\hline $\mathrm{K}_{2} \mathrm{O}$ & $<$ d.1. & 0.13 & 0.05 & 0.08 & & \\
\hline Total & 96.42 & 97.99 & 97.49 & 97.55 & & \\
\hline \multicolumn{7}{|l|}{ Cations } \\
\hline $\mathrm{Si}$ & 7.672 & 6.356 & 7.611 & 6.558 & & \\
\hline $\mathrm{Al}^{\mathrm{IV}}$ & 0.285 & 1.644 & 0.389 & 1.442 & & \\
\hline $\mathrm{Al}^{\mathrm{VI}}$ & 0.000 & 0.502 & 0.135 & 0.516 & & \\
\hline $\mathrm{Ti}$ & 0.006 & 0.092 & 0.025 & 0.021 & & \\
\hline $\mathrm{Fe}^{2+}$ & 0.274 & 1.553 & 0.652 & 1.140 & & \\
\hline $\mathrm{Mn}$ & 0.024 & 0.014 & 0.009 & 0.005 & & \\
\hline $\mathrm{Mg}$ & 4.844 & 2.967 & 4.322 & 3.406 & & \\
\hline $\mathrm{Ca}$ & 2.072 & 1.882 & 1.825 & 1.884 & & \\
\hline $\mathrm{Na}$ & 0.000 & 0.852 & 0.255 & 0.800 & & \\
\hline K & 0.000 & 0.024 & 0.009 & 0.015 & & \\
\hline $\mathrm{Mg \#}$ & 0.946 & 0.656 & 0.869 & 0.749 & & \\
\hline Name: & Tremolite & Pargasitic hornblende & Tremolite & Hornblende & & \\
\hline Description: & In vein & Vein edge & In vein & Vein center & & \\
\hline
\end{tabular}

Notes: $\ddagger=$ three analyses from same zoned grain, $*=\mathrm{Mg} \#=\mathrm{Mg} /\left(\mathrm{Mg}+\mathrm{Fe}^{2+}\right),<\mathrm{d} . \mathrm{I} .=$ below detection limit. 
Table 3. Representative vein chlorite data.

\begin{tabular}{|c|c|c|c|c|c|}
\hline Sample: & $\begin{array}{c}153-921 \mathrm{D}-2 \mathrm{R}-1 \\
94-99 \mathrm{~cm}\end{array}$ & $\begin{array}{c}153-923 \mathrm{~A}-16 \mathrm{R}-4, \\
79-85 \mathrm{~cm}\end{array}$ & $\begin{array}{c}153-923 \mathrm{~A}-16 \mathrm{R}-2 \\
41-46 \mathrm{~cm}\end{array}$ & $\begin{array}{c}153-924 \mathrm{~B}-5 \mathrm{R}-1 \\
34-40 \mathrm{~cm}\end{array}$ & $\begin{array}{c}153-924 C-7 R-1 \\
46-52 \mathrm{~cm}\end{array}$ \\
\hline \multicolumn{6}{|l|}{ Oxide (wt $\%$ ) } \\
\hline $\mathrm{SiO}_{2}$ & 31.64 & 31.05 & 30.39 & 34,05 & 30.65 \\
\hline $\mathrm{TiO}_{2}^{2}$ & 0.00 & 0.02 & 0.00 & 0.00 & 0.04 \\
\hline $\mathrm{Al}_{2} \mathrm{O}_{3}$ & 15.42 & 12.67 & 16.78 & 15.39 & 18.96 \\
\hline $\mathrm{Cr}_{2} \mathrm{O}_{3}$ & $<$ d.l. & NA & $\mathrm{NA}$ & $\mathrm{NA}$ & $<$ d.l. \\
\hline $\mathrm{FeO}^{*}$ & 19.00 & 23.99 & 19.99 & 12.17 & 11.09 \\
\hline $\mathrm{MnO}$ & 0.28 & 0.21 & 0.16 & 0.28 & 0.20 \\
\hline $\mathrm{MgO}$ & 20.99 & 20.18 & 22.34 & 24.49 & 26.00 \\
\hline $\mathrm{CaO}$ & 0.19 & 0.05 & 0.01 & 0.13 & 0.65 \\
\hline $\mathrm{Na}_{2} \mathrm{O}$ & 0.17 & 1.63 & 1.07 & 0.17 & 0.05 \\
\hline $\mathrm{K}_{2} \mathrm{O}$ & 0.10 & 0.05 & 0.04 & 0.05 & 0.03 \\
\hline Total & 87.64 & 89.85 & 90.78 & 85.73 & 87.66 \\
\hline \multicolumn{6}{|l|}{ Cations } \\
\hline $\mathrm{Si}$ & 5.50 & 4.87 & 4.66 & 5.73 & 5.12 \\
\hline $\mathrm{Ti}$ & 0.00 & 0.00 & 0.00 & 0.00 & 0.00 \\
\hline $\mathrm{Al}$ & 3.13 & 2.34 & 3.03 & 3.05 & 3.73 \\
\hline $\mathrm{Fe}$ & 2.76 & 3.15 & 2.56 & 1.71 & 1.55 \\
\hline $\mathrm{Mn}$ & 0.04 & 0.03 & 0.02 & 0.04 & 0.03 \\
\hline $\mathrm{Mg}$ & 5.44 & 4.72 & 5.11 & 6.15 & 6.47 \\
\hline $\mathrm{Ca}$ & 0.03 & 0.01 & 0.00 & 0.02 & 0.12 \\
\hline $\mathrm{Na}$ & 0.06 & 0.50 & 0.32 & 0.06 & 0.02 \\
\hline $\mathrm{K}$ & 0.02 & 0.01 & 0.01 & 0.01 & 0.01 \\
\hline $\mathrm{Mg} / \mathrm{Mg}+\mathrm{Fe}^{2+}$ & 0.67 & 0.60 & 0.67 & 0.78 & 0.81 \\
\hline
\end{tabular}

Notes: * = all $\mathrm{Fe}$ as $\mathrm{FeO} ; \mathrm{NA}=$ not analyzed; $<\mathrm{d} . \mathrm{I}$. = below detection limit.

Figure 19. Backscattered electron image of an amphibole vein in Sample 153-921B-4R-1, 80-84 cm. The vein contains Na plagioclase of $\mathrm{An}_{14}-\mathrm{An}_{17}$ (plg; black), amphibole (amph; gray) of varying compositions (from hornblende to actinolite), and secondary clinopyroxene ( $\mathrm{cpx} 2$; brightest phase with zoning).

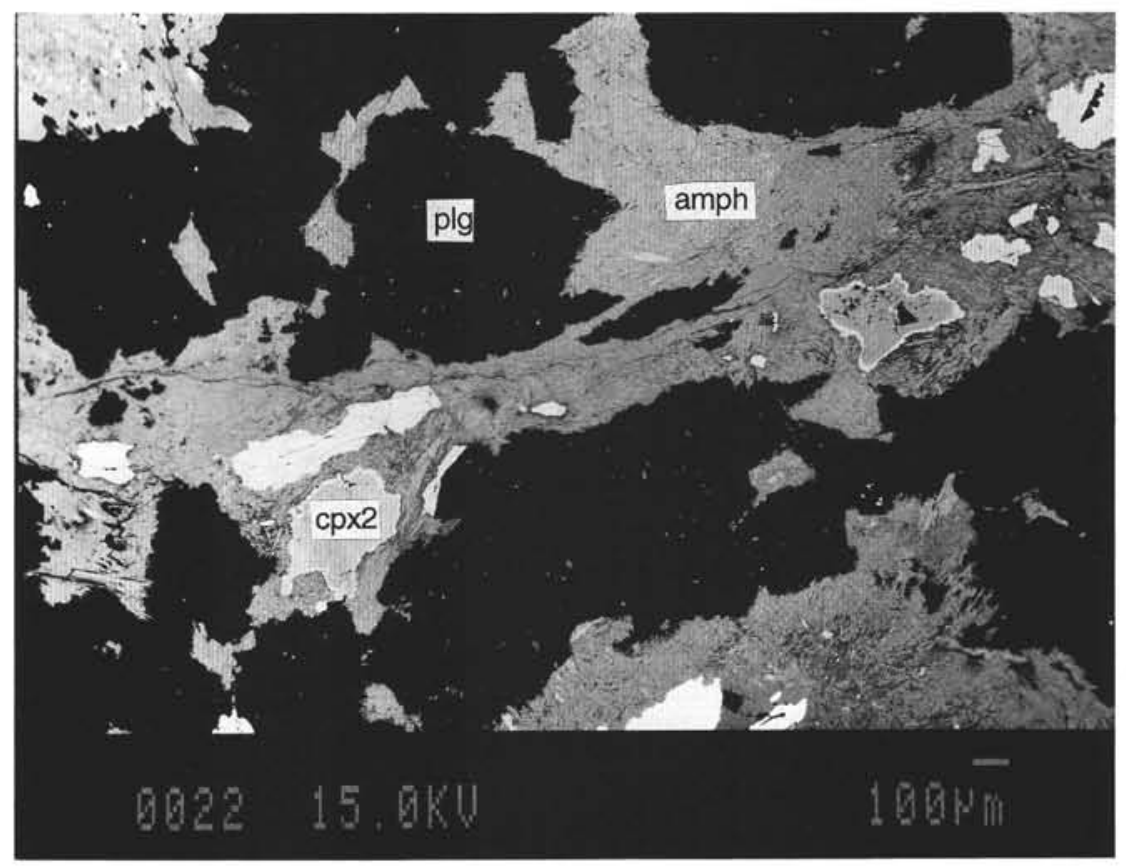

consistent with observations and data from gabbroic rocks recovered from Hole 735B at the Atlantis II Fracture Zone along the Southwest Indian Ridge (Cannat et al., 1991a, 199lb; Dick et al., 1991a, 1991b; Mével and Cannat, 1991; Robinson et al., 1991; Stakes et al., 1991; Vanko and Stakes, 1991; Magde et al., 1995). However, the characteristic features of the deformation fabrics and metamorphic assemblages in the Site 735 gabbros suggest that deformation at Hole 735B was started at hypersolidus conditions and continued from granulite to amphibolite facies $\left(550^{\circ}-850^{\circ} \mathrm{C}\right)$ conditions (Cannat et al., $1991 \mathrm{~b}$; Dick et al., 1991b; Mével et al., 1991; Stakes et al., 1991; Vanko and Stakes, 1991; Gillis et al., 1993; Magde et al., 1995); deformation in the MARK area, however, was initiated at amphibolite facies $\left(550^{\circ}-\right.$ $700^{\circ} \mathrm{C}$ ) conditions (Mével and Cannat, 1991; Gillis et al., 1993; Kelley et al., 1993; Kelley, this volume). These differences probably reflect some variations in the mode and nature of the magmatic and tectonic extension and their spatial and temporal interplay in each re- gion. However, the lower oceanic crust in both of these slow-spreading ridge environments displays a progressive evolution from magmatic to low-temperature metamorphic conditions that accompanied tectonic stretching and lithospheric extension. Initial penetration of fluid flow into the lower crust of slow-spread oceanic lithosphere was facilitated by ductile shear zones when the temperature conditions were still high (Cannat et al., 1991b; Dick et al., 1991b; Gillis et al. 1993; this study). This phenomenon results in a heterogeneous distribution of high-temperature alteration in slow-spread oceanic crust, unlike in fast-spread oceanic crust in which hydration at high temperatures takes place uniformly along microfracture and crack networks in the absence of ductile shear zones (Früh-Green et al., 1994; Gillis, 1994).

The findings of detailed studies of fossil hydrothermal systems and vein networks in the Semail ophiolite (Oman), which is interpreted to represent a remnant of an intermediate- to fast-spread oceanic 


\section{VEIN AMPHIBOLES}

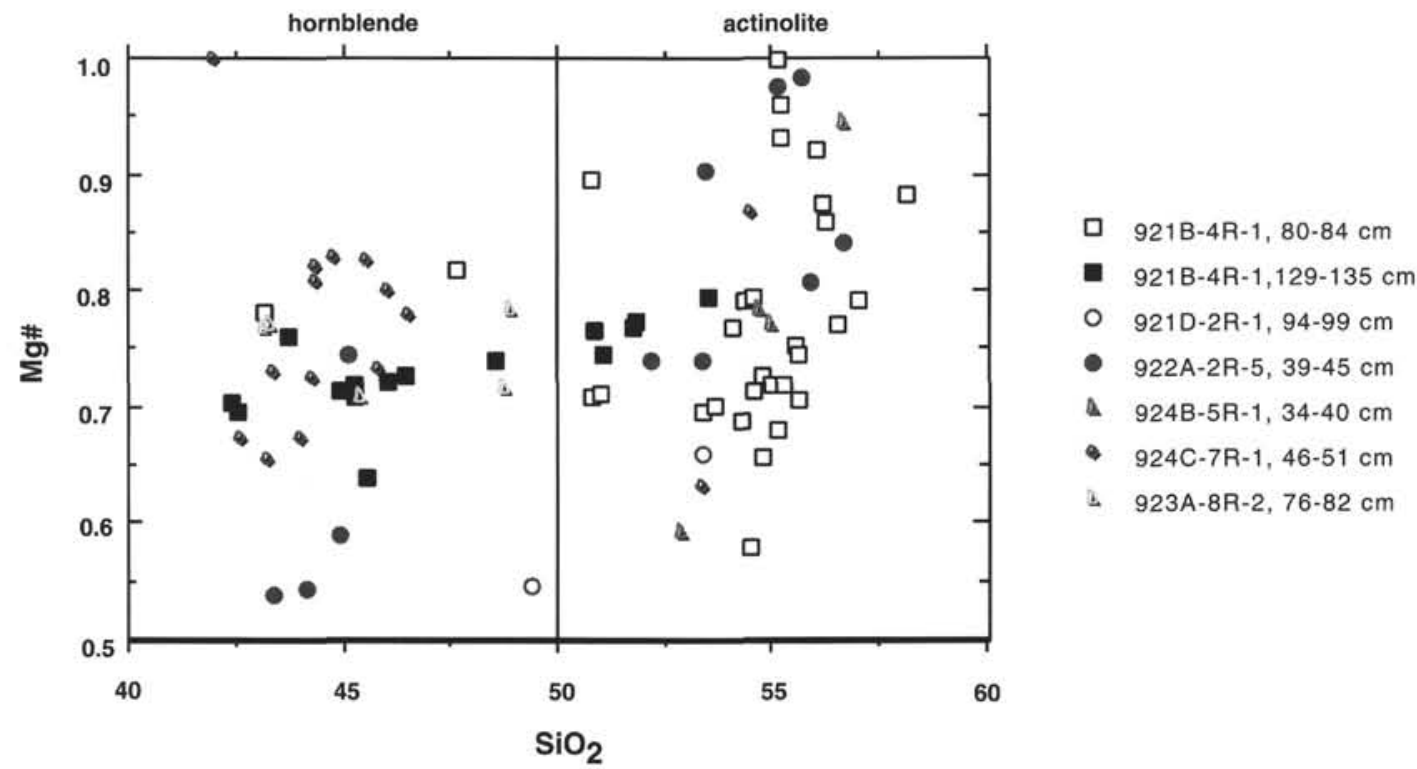

Figure 20. $\mathrm{SiO}_{2}$ vs. Mg\# of selected amphiboles from hydrothermal veins. See text for discussion.

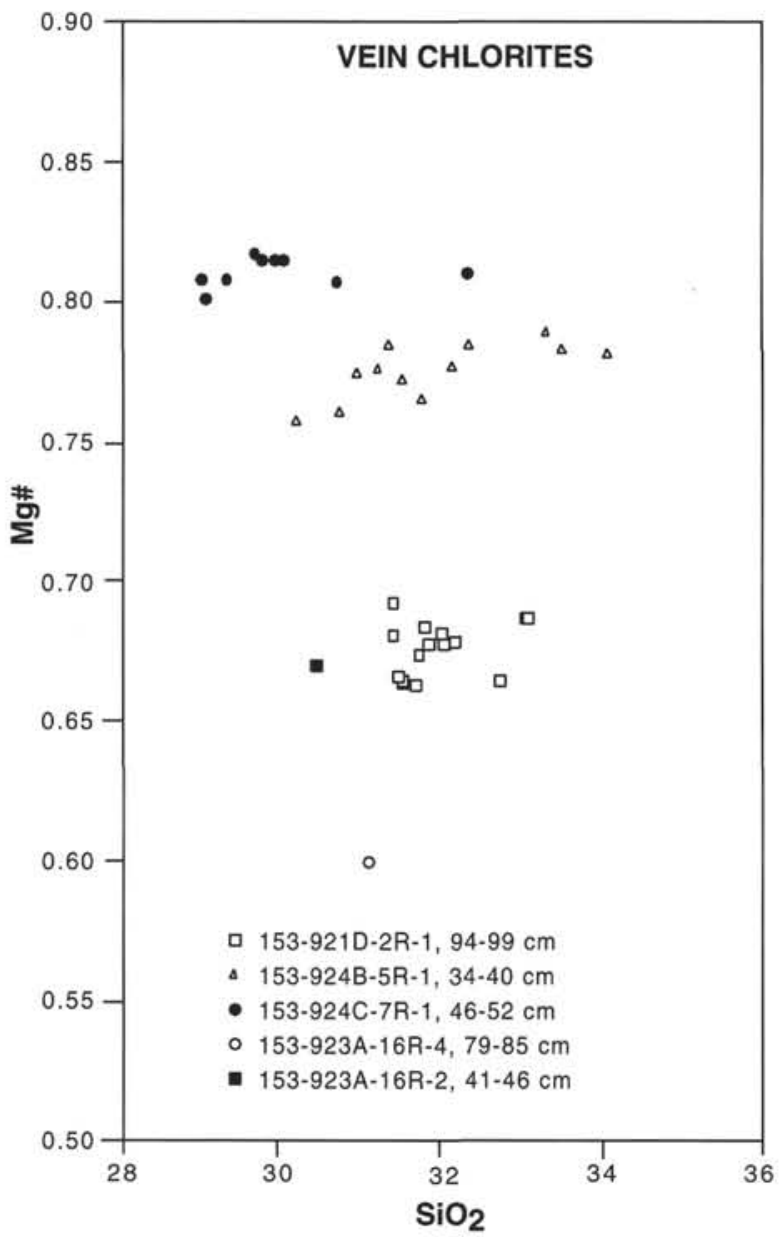

Figure $21 . \mathrm{SiO}_{2}$ vs. $\mathrm{Mg \#}$ of selected chlorites from hydrothermal veins. See text for discussion. lithosphere (Nicolas, 1989), are consistent with these observations from modern fast-spreading oceanic crust and suggest that the earliest stages of hydrothermal alteration in the Semail gabbros were associated with a network of mm-scale, subparallel amphibole veins, which had developed as a result of cracking front (Nehlig, 1993, 1994). The vein system in the transition zone (between the sheeted dike complex and the gabbros) and in the high-level gabbros in the Semail ophiolite is highly anisotropic (subparallel to the sheeted dikes and perpendicular to the layering in the cumulates), and consists of amphiboles with compositions varying from actinolitic hornblende to actinolite. Vein density and associated hydrothermal alteration decrease downward in the gabbros, and the underlying cumulate gabbros are almost unaltered displaying only a diffuse net of amphibole veins (Nehlig, 1993). These relations show that hydrothermal circulation in the fast-spread lower crust was facilitated by generation of cracks in a regional stress field along the spreading system (Nehlig, 1994). Development of cracks and hydrothermal veins occurred in this case as a result of downward propagation of cracking front and attendant hydrothermal circulation with further cooling of the gabbros below $500^{\circ} \mathrm{C}$ and after the crystallization of the cumulates. These observations and interpretations suggest that the significant differences in alteration patterns between the slow-spreading and fast-spreading oceanic crust result from the spatial and temporal relations between lithospheric deformation and hydrothermal alteration in the absence (or presence) of a steady-state magma chamber.

\section{ACKNOWLEDGMENTS}

This work was supported by a grant from JOI-USSAC to Y.D. The authors thank the Shipboard Scientific Party of ODP Leg 153 for fruitful discussions on different aspects of the structure and hydrothermal alteration of gabbroic rocks. Critical but constructive comments by M. Cannat, P. Nehlig, and an anonymous reviewer improved the paper. 

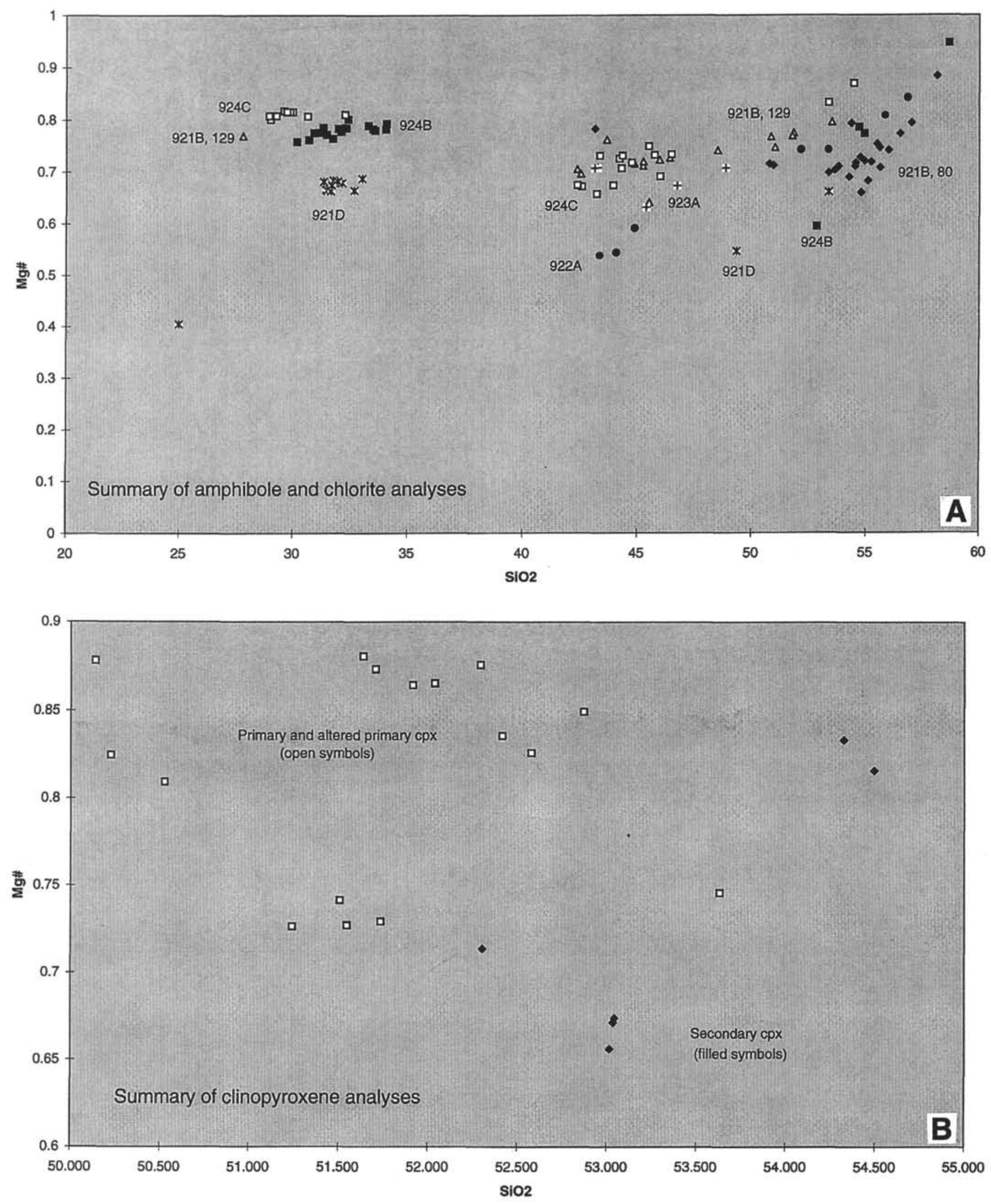

Figure 22. A. Compositional variations $\left(\mathrm{SiO}_{2}\right.$ vs. $\mathrm{Mg \#}$ ) of representative amphiboles (on the right) and chlorites (on the left) from Site 921 to 924 gabbroic rocks. B. Compositional variations $\left(\mathrm{SiO}_{2}\right.$ vs. $\mathrm{Mg} \#$ ) of representative primary and secondary clinopyroxenes (cpx) from Site 921 to 924 gabbroic rocks. See text for discussion. 
Table 4. Representative clinopyroxene (primary and altered primary adjacent to and secondary in hydrothermal veins) data from gabbroic rocks (Sites 921-924, MARK area).

\begin{tabular}{|c|c|c|c|c|c|c|c|}
\hline Sample: & $\begin{array}{c}153-921 \mathrm{~B}-4 \mathrm{R}-1 \\
80-84 \mathrm{~cm}\end{array}$ & $\begin{array}{c}153-921 \mathrm{~B}-4 \mathrm{R}-1 \\
80-84 \mathrm{~cm}\end{array}$ & $\begin{array}{c}153-924 \mathrm{C}-7 \mathrm{R}-1 \\
46-52 \mathrm{~cm}\end{array}$ & $\begin{array}{c}153-921 \mathrm{~B}-4 \mathrm{R}-1 \\
80-84 \mathrm{~cm}\end{array}$ & $\begin{array}{c}153-921 \mathrm{~B}-4 \mathrm{R}-1 \\
129-135 \mathrm{~cm}\end{array}$ & $\begin{array}{c}153-921 \mathrm{~B}-4 \mathrm{R}-1 \\
80-84 \mathrm{~cm}\end{array}$ & $\begin{array}{c}153-92 \text { IB-4R-1, } \\
129-135 \mathrm{~cm}\end{array}$ \\
\hline \multicolumn{8}{|l|}{ Oxide (wt $\%$ ) } \\
\hline $\mathrm{SiO}_{2}$ & 53.04 & 53.04 & 52.30 & 51.71 & 50.23 & 51.64 & 50.53 \\
\hline $\mathrm{TiO}_{2}$ & 0.21 & 0.00 & 0.06 & 0.32 & 0.39 & 0.38 & 0.87 \\
\hline $\mathrm{Al}_{2} \mathrm{O}_{3}$ & 0.77 & 1.43 & 3.40 & 3.67 & 3.91 & 3.44 & 2.98 \\
\hline $\mathrm{Cr}_{2} \mathrm{O}_{3}$ & 0.02 & 0.02 & 0.00 & 1.16 & 1.26 & 1.06 & 0.41 \\
\hline $\mathrm{FeO}^{*}$ & 10.00 & 9.60 & 8.33 & 4.19 & 5.79 & 3.95 & 6.51 \\
\hline $\mathrm{MnO}$ & 0.52 & 0.55 & 0.72 & 0.15 & 0.13 & 0.10 & 0.19 \\
\hline $\mathrm{CaO}$ & 24.76 & 24.35 & 22.64 & 22.60 & 20.11 & 22.64 & 20.67 \\
\hline $\mathrm{Na}_{2} \mathrm{O}$ & 0.40 & 0.47 & 0.68 & 0.39 & 0.39 & 0.39 & 0.37 \\
\hline $\mathrm{K}_{2} \mathrm{O}$ & 0.00 & 0.00 & 0.00 & 0.00 & 0.00 & 0.02 & 0.00 \\
\hline Total & 101.17 & 101.39 & 99.78 & 100.37 & 97.42 & 99.95 & 98.01 \\
\hline \multicolumn{8}{|l|}{ Cations } \\
\hline $\mathrm{Si}$ & 7.93 & 7.94 & 7.82 & 7.56 & 7.58 & 7.58 & 7.61 \\
\hline $\mathrm{Ti}$ & 0.02 & 0.00 & 0.01 & 0.04 & 0.05 & 0.04 & 0.10 \\
\hline $\mathrm{Al}$ & 0.14 & 0.25 & 0.60 & 0.63 & 0.70 & 0.60 & 0.53 \\
\hline $\mathrm{Fe}$ & 1.25 & 1.20 & 1.04 & 0.51 & 0.73 & 0.48 & 0.82 \\
\hline $\mathrm{Mn}$ & 0.07 & 0.07 & 0.09 & 0.02 & 0.02 & 0.01 & 0.02 \\
\hline $\mathrm{Ca}$ & $<$ d.l. & $<$ d.1. & 0.20 & $<$ d.l. & $<$ d.l. & $<$ d.I. & $<$ d.1. \\
\hline $\mathrm{Na}$ & 0.12 & 0.12 & 0.32 & 0.11 & 0.11 & 0.11 & 0.11 \\
\hline $\mathrm{K}$ & 0.00 & 0.00 & 0.00 & 0.00 & 0.00 & 0.00 & 0.00 \\
\hline $\mathrm{Mg} /\left(\mathrm{Mg}+\mathrm{Fe}^{2+}\right)$ & 0.67 & 0.67 & 0.71 & 0.87 & 0.82 & 0.88 & 0.81 \\
\hline Description & Secondary in vein & Secondary in vein & Secondary in vein & $\begin{array}{l}\text { Primary, adjacent } \\
\text { to amphibole } \\
\text { vein }\end{array}$ & $\begin{array}{l}\text { Primary, adjacent } \\
\text { to amphibole } \\
\text { vein }\end{array}$ & $\begin{array}{l}\text { Altered primary, } \\
\text { adjacent to } \\
\text { amphibole vein }\end{array}$ & $\begin{array}{l}\text { Altered primary } \\
\text { adjacent to } \\
\text { amphibole vein }\end{array}$ \\
\hline
\end{tabular}

Note: Symbols and abbreviations as in Table 3.

\section{REFERENCES}

Auzende, J.M., Cannat, M., Gente, P., Henriet, J.P., Juteau, T., Karson, J.A., Lagabrielle, Y., and Tivey, M.A., 1993. Deep layers of mantle and oceanic crust exposed along the southern wall of the Kane Fracture Zone: submersible observations. C.R. Acad. Sci. Ser. 2, 317:1641-1648.

Blundy, J.D., and Holland, T.J.B., 1990. Calcic amphibole equilibria and a new amphibole-plagioclase geothermometer. Contrib. Mineral. Petrol., 104:208-224.

Cannat, M., 1991. Plastic deformation at an oceanic spreading ridge: a microstructural study of Site 735 gabbros (southwest Indian Ocean). In Von Herzen, R.P., Robinson, P.T., et al., Proc. ODP, Sci. Results, 118: College Station, TX (Ocean Drilling Program), 399-408.

Cannat, M., Karson, J.A., Miller, D.J., et al., 1995. Proc. ODP, Init. Repts., 153: College Station, TX (Ocean Drilling Program).

Cannat, M., Mével, C., Maia, M., Deplus, C., Durand, C., Gente, P., Agrinier, P., Belarouchi, A., Dubuisson, G., et al., 1995. Thin crust, ultramafic exposures, and rugged faulting patterns at the Mid-Atlantic Ridge $\left(22^{\circ}-\right.$ $\left.24^{\circ} \mathrm{N}\right)$. Geology, 23:49-52.

Cannat, M., Mével, C., and Stakes, D., 1991a. Normal ductile shear zones at an oceanic spreading ridge: tectonic evolution of Site 735 gabbros (southwest Indian Ocean). In Von Herzen, R.P., Robinson, P.T., et al., Proc. ODP, Sci. Results, 118: College Station, TX (Ocean Drilling Program), 415-429.

, 1991b. Stretching of the deep crust at the slow spreading SW Indian Ridge. Tectonophysics, 190:73-95.

Cathelineau, M., and Nieva, D., 1985. A chlorite solid solution geothermometer: the Loz Azufres (Mexico) geothermal system. Contrib. Mineral. Petrol., 91:235-244.

Dick, H.J.B., Meyer, P.S., Bloomer, S., Kirby, S., Stakes, D., and Mawer, C., 1991a. Lithostratigraphic evolution of an in-situ section of oceanic Layer 3. In Von Herzen, R.P., Robinson, P.T., et al., Proc. ODP. Sci. Results, 118: College Station, TX (Ocean Drilling Program), 439-538.

Dick, H.J.B., Thompson, G., and Bryan, W.B., 1981. Low angle faulting and steady state emplacement of plutonic rocks at ridge-transform intersections. Eos, 62:406.

Dick, H.J.B., Schouten, H., Meyer, P.S., Gallo, D.G., Bergh, H., Tyce, R., Patriat, P., Johnson, K.T.M., Snow, J., and Fisher, A., 1991b. Tectonic evolution of the Atlantis II Fracture Zone. In Von Herzen, R.P., Robinson, P.T., et al., Proc. ODP, Sci. Results, 118: College Station, TX (Ocean Drilling Program), 359-398.
Früh-Green, G.L., Plas, A., Dell'Angelo, L.N., and Lécuyer, C., 1994. Multistage hydrothermal alteration of the EPR lower crust and shallow mantle at Hess Deep: mineralogical and stable isotope constraints. Eos, 75:649 650 .

Gillis, K.M., 1994. Mineralogical constraints on the magma-hydrothermal transition in oceanic hydrothermal systems. Eos, 75:649.

Gillis, K.M., Thompson, G., and Kelley, D.S., 1993. A view of the lower crustal component of hydrothermal systems at the Mid-Atlantic Ridge. J. Geophys. Res., 98:19597-19619.

Karson, J.A., and Dick, H.J.B., 1983. Tectonics of ridge-transform intersections at the Kane Fracture Zone. Mar. Geophys. Res., 6:51-98.

Karson, J.A., Thompson, G., Humphris, S.E., Edmond, J.M., Bryan, W.B., Brown, J.R., Winters, A.T., Pockalny, R.A., Casey, J.F., Campbell, A.C., Klinkhammer, G., Palmer, M.R., Kinzler, R.J., and Sulanowska, M.M., 1987. Along-axis variations in seafloor spreading in the MARK area. Nature, 328:681-685.

Kelley, D.S., and Delaney, J.R., 1987. Two-phase separation and fracturing in mid-ocean ridge gabbros at temperatures greater than $700^{\circ} \mathrm{C}$. Earth Planet. Sci. Lett., 83:53-66.

Kelley, D.S., Gillis, K.M., and Thompson, G., 1993. Fluid evolution in submarine magma-hydrothermal systems at the Mid-Atlantic Ridge. J. Geophys. Res., 98:19579-19596.

Leake, B.E., 1978. Nomenclature of amphiboles. Contrib. Mineral. Petrol. 31:171-177.

Liou, J.G., Kuniyoshi, S., and Ito, K., 1974. Experimental studies of the phase relations between greenschist and amphibolite in a basaltic system. Am. J. Sci., 274:613-632.

Magde, L.S., Dick, H.J.B., and Hart, S.R., 1995. Tectonics, alteration and fractal distribution of hydrothermal veins in the lower ocean crust. Earth Planet. Sci. Lett., 129:103-119.

Marion, E., Mével, C., and Cannat, M., 1991. Evolution of oceanic gabbros from the MARK/Kane fracture intersection massif. Terra Abstr., 3:310.

Mével, C., and Cannat, M., 1991. Lithospheric stretching and hydrothermal processes in oceanic gabbros from slow-spreading ridges. In Peters, T., Nicolas, A., and Coleman, R.J. (Eds.), Ophiolite Genesis and Evolution of the Oceanic Lithosphere. Petrol. Struct. Geol., 5:293-312.

Mével, C., Cannat, M., Gente, P., Marion, E., Auzende, J.-M., and Karson, J.A., 1991. Emplacement of deep crustal and mantle rocks on the west median valley wall of the MARK area (MAR $\left.23^{\circ} \mathrm{N}\right)$. Tectonophysics, 190:31-53.

Mottl, M.J., 1983. Metabasalts, axial hot springs, and the structure of hydrothermal systems at mid-ocean ridges. Geol. Soc. Am. Bull., 94:161-180. 
Nehlig, P., 1993. Interactions between magma chambers and hydrothermal systems: oceanic and ophiolitic constraints. J. Geophys. Res., 98:1962119633.

1994. Fracture and permeability analysis in magma-hydrothermal transition zones in the Samail ophiolite (Oman). J. Geophys. Res., 99:589-601.

Nicolas, A., 1989. Structure of Ophiolites and Dynamics of the Oceanic Lithosphere: Dordrecht (Kluwer)

Ramsay, J.G., and Huber, M.I., 1983. The Techniques of Modern Structural Geology (Vol. 1): Strain Analysis: London (Acad. Press).

Robinson, P., Spear, F.S., Schumacher, J.C., Laird, J., Klein, C., Evans, B.W., and Doolan, B.L.. 1982. Phase relations of metamorphic amphiboles: natural occurrence and theory. In Veblen, D.R., and Ribbe, P.H. (Eds.), Amphiboles: Petrology and Experimental Phase Relations. Rev. Mineral., 9B:1-227.

Robinson, P.T., Dick, H.J.B., and Von Herzen, R.P., 1991. Metamorphism and alteration in oceanic layer 3: Hole 735B. In Von Herzen, R.P., Robinson, P.T., et al., Proc. ODP, Sci. Results, 118: College Station, TX (Ocean Drilling Program), 541-552.

Seyfried, W.E., Jr., Berndt, M.E., and Seewald, J.S., 1988. Hydrothermal alteration processes at mid-ocean ridges: constraints from diabase alter- ation experiments, hot-spring fluids and composition of the oceanic crust. Can. Mineral., 26:787-804.

Shipboard Scientific Party, 1995. Explanatory notes. In Cannat, M., Karson, J.A., Miller, D.J., et al., Proc. ODP, Init. Repts., 153: College Station, TX (Ocean Drilling Program), 15-42.

Spear, F.S., 1980. NaSiCaAl exchange equilibrium between plagioclase and amphibole: an empirical model. Contrib. Mineral. Petrol., 72:33-41.

Stakes, D., Mével, C., Cannat, M., and Chaput, T., 1991. Metamorphic stratigraphy of Hole 735B. In Von Herzen, R.P., Robinson, P.T., et al., Proc. ODP, Sci. Results, 118: College Station, TX (Ocean Drilling Program), 153-180.

Vanko, D.A., and Stakes, D.S., 1991. Fluids in oceanic layer 3: evidence from veined rocks, Hole 735B, Southwest Indian Ridge. In Von Herzen, R.P., Robinson, P.T., et al., Proc. ODP, Sci. Results, 118: College Station, TX (Ocean Drilling Program), 181-215.

Date of initial receipt: 15 August 1995

Date of acceptance: 29 April 1996

Ms 153SR-011 